\title{
DEPARTMEIVT OF COMIMERCE
} BUREAU OF FISHERIES

HUGH M. SMITH, Commissioner

\section{THE MUSSEL RESOURCES OF THE ILLINOIS RIVER}

BY ERNEST DANGLADE

Scientific Assistant, U. S. Burreati of Fisheries

\section{THE IIUSSEL FISHERY OF THE FOX RIVER}

By JOHN A. ELDRIDGE

APPENDIXES VI AND VII TO THE REPORT OF THE U. S: COMIMISSIONER OF FISHERIES FOR 1913

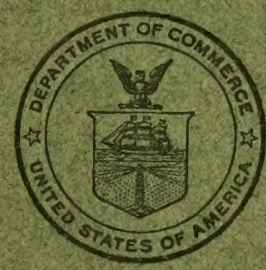

Bureau of Fisheties Document No. 804

* WASHINGTON

GOVERNMENT PRINTING OFFICB 1914 





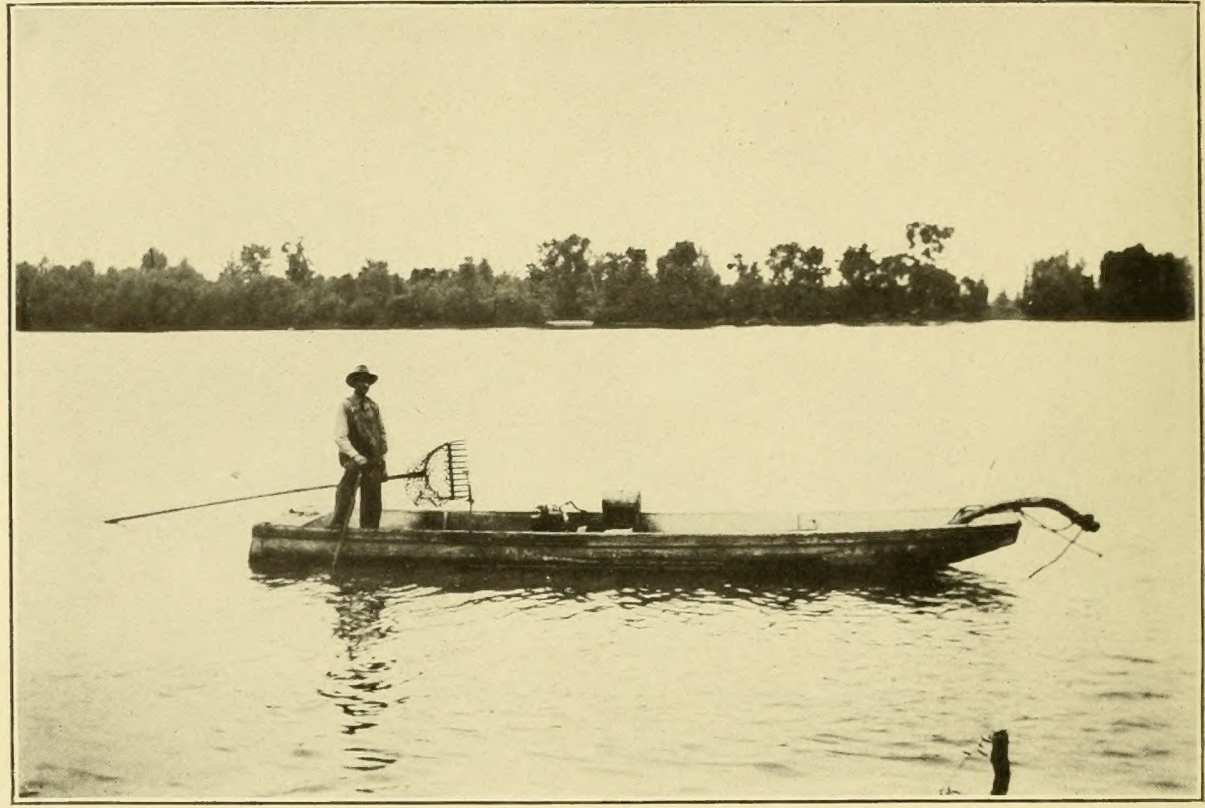

FIG. 1.-A MUSSEL FISHERMAN.

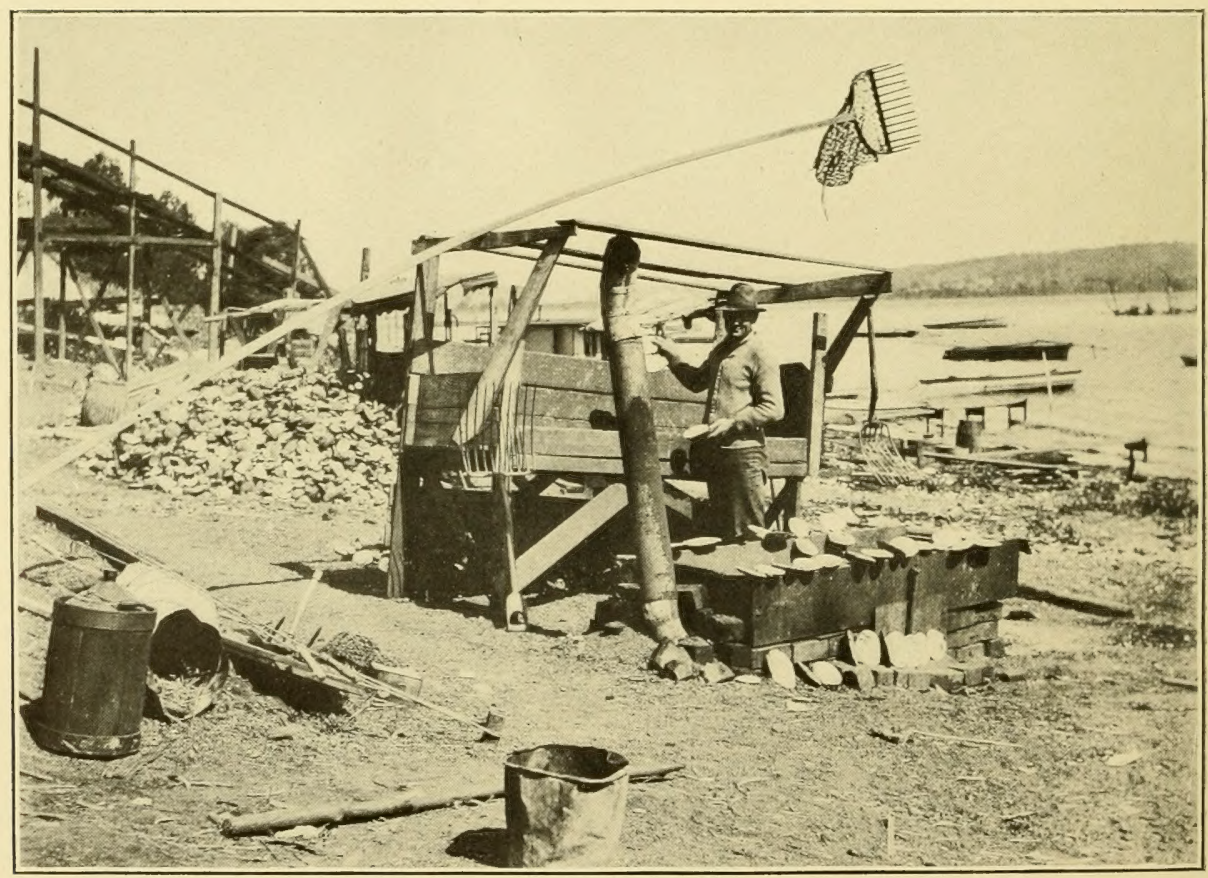

FIG. 2.-A PEARL GATHERER AND HIS CAMP OUTFIT. 


\section{DEPARTMENT OF COMMERCE}

BUREAU OF FISHERIES

HUGH M. SMITH, Commissiones

\section{THE MUSSEL RESOURCES OF THE ILLINOIS RIVER}

By ERNEST DANGLADE

Scientific Assistant, U. S. Burreaus of Fisheries

\section{THE MUSSEL FISHERY OF THE FOX RIVER}

By JOHN A. ELDRIDGE

APPENDIXES VI AND VII TO THE REPORT OF THE U. S. COMMISSIONER OF FISHERIES FOR 1913

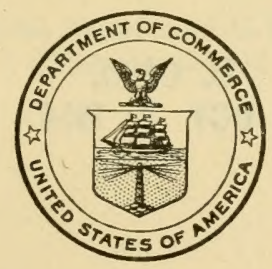

Bureau of Fisheries Document No. 804

WASHINGTON

GOVERNMENT PRINTING OFFICE 1914 


\section{SH 379 \\ 4513}

ADDITIONAL COPIES

OF THIS PUBLICATION MAY BE PROCURED FROM THE SUPERINTENDENT OF DOCUMENTS GOVERNMENT PRINTING OFFICE WASHINGTON, D. C.

AT

15 CEN'TS PER COPY

\section{OF D. \\ OCT 71914}

$\because \vdots$ 


\title{
THE MUSSEL RESOURCES OF THE ILLINOIS RIVER
}

\author{
By ERNEST DANGLAdE \\ Scientific Assistant, U. S. Bureau of Fisheries
}

Appendix VI to the Report of the U. S. Commissioner of Fisheries for 1913 
C O N T E T S.

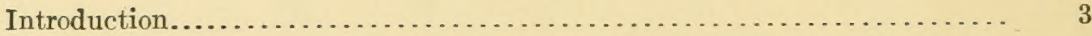

Physical conditions . . . . . . . . . . . . . . . . . . . . . . . . . . . . . 4

Pollution of the Illinois River............................. 5

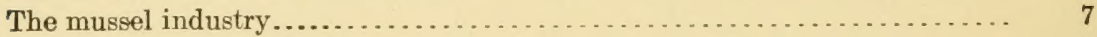

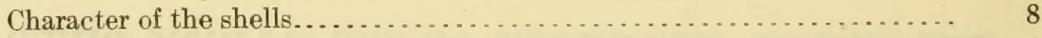

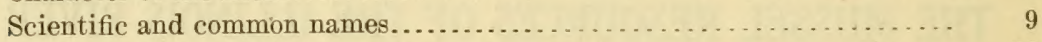

Commercial appraisal of quantity of shells..................... 10

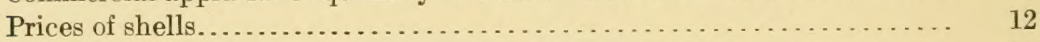

Principal mussel beds.................................... 13

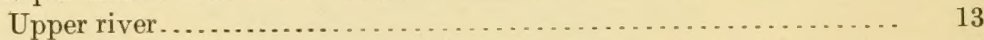

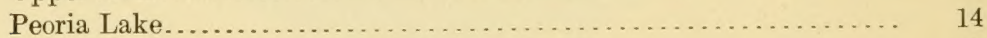

Lower river. . . . . . . . . . . . . . . . . . . . . . . . . . . 17

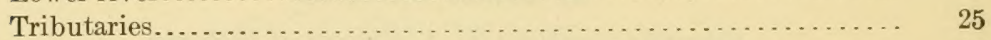

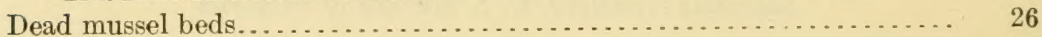

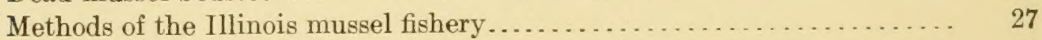

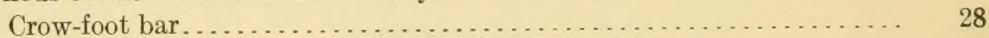

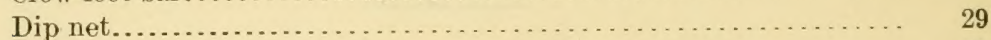

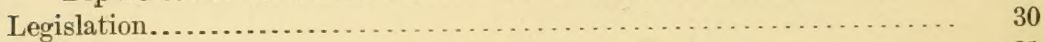

The pearls of the Illinois. . . . . . . . . . . . . . . . . . . . . . . . 31

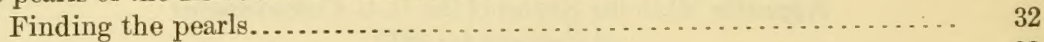

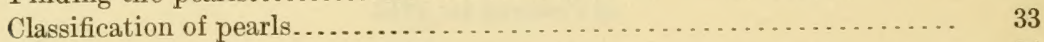

Position of pearls in mussel shells.......................... 34

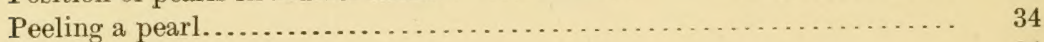

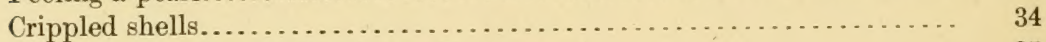

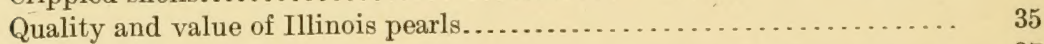

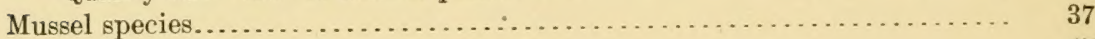

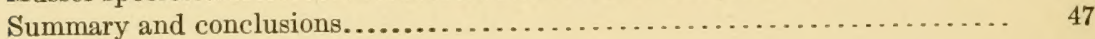




\title{
THE MUSSEL RESOURCES OF THE ILLINOIS RIVER.
}

\author{
By Ernest Danglade, \\ Scientific Assistant, U. S. Bureau of Fisheries.
}

\section{INTRODUCTION.}

The Bureau of Fisheries conducted a series of investigations of the Illinois River, principally during the summer months of the period extending from 1907 to 1912. The work was carried on chiefly with regard to the mussel fishery; the kinds, the quality and quantity of shells, and also the general economic conditions of the river were the important points under consideration. From 1907 to 1909 the work was in charge of Harvey L. Freeland, and during 1912 the mussel investigation of the entire river was continued by the author and John A. Danglade. For several years the Illinois State Laboratory of Natural IIistory, with some assistance from the Tirited States Bureau of Fisheries, conducted biological and physical investigations of the river, under the direction of Prof. S. A. Forbes.

The principal shell-producing tributaries of the Illinois are the Kankicion, ${ }^{a}$ which has been examined and reported upon; the Fox, the repurt of which by John A. Eldridge accompanies this paper; the Spoon and the Sangamon, brief accounts of which are given in the body of the present report.

The United States biological station, situated at Fairport, Iowa, in charge of Dr. Robert E. Coker, furnished valuable information and suggestions, which were of great assistance to the work. The table of the commercial appraisal of shells, made by the shell expert, given on page 11, shows the condition of shells as to luster, texture, and number of gross of blanks per ton, from various representative stations of the river. The map of the Illinois and Fox Rivers, at the end of this paper, gives the principal tributaries, towns, and cities along the course, and shows to some extent the islands, lakes, sloughs, bays, etc.

The following report of the river is intended principally for the benefit of those engaged in the pearl-button industry either as manufacturers or mussel fishermen, and for others interested in the development of the mussel resources of the country.

$a$ Wilson, Charles B., and Clark, H. Walton: The mussel fauna of the Kankakee Basin. U. S. Bureau of Fisheries Document No. 758. 1912. 


\section{PHYSICAL CONDITIONS.}

The Illinois River is one of the most important tributaries of the upper Mississippi, not only on account of the volume of water it discharges and its excellent transportation facilities, but because of its extensive fisheries and large mussel resources. The Illinois, formed by the junction of the Kankakee and Des Plaines Rivers and emptying into the Mississippi at Grafton, Ill., is about 273 miles in length. Its drainage basin comprises about 29,000 square miles of fine farm land in Illinois, Indiana, and Wisconsin. Besides receiving many important natural tributaries, it is the outlet of the Chicago Drainage Canal, having a discharge of several thousand cubic feet per second of water from Lake Michigan, and with an equivalent drainage area of 6,000 square miles. The river consequently carries an enormous amount of sewage from Chicago, as well as from the various cities and manufacturing plants along its course.

The greater part of Illinois is covered by glacial drift of varying thickness, brought down from the Northeast during the ice age, and as a consequence many of the old river beds were filled with sand and gravel and the streams were torced to cut new channels, in some places completely changing the course for all or a part of the way. Such is the case with the Illinois River. In the upper part the river has cut its way through the Wisconsin drift down into solid rock, while in the lower portion, although still in its old course, it is often as much as 100 feet above solid rock.

The watershed of the Illinois River extends in a broad band, averaging 100 miles in width, in a northeast-southwest direction directly across the center of Illinois. The western side of the watershed is 20 to 40 miles in width, while the width of the eastern side is 60 to 80 miles. From the junction westward for 50 miles, being in a new course, its bed is usually on the rock.and it has an average fall of about 1 foot per mile, but in the remainder of its course it is in a preglacial channel and has a very slight fall. From the junction to Utica, its course is independent of preglacial drainage lines. About midway of its westward course it crosses the Marseilles moraine. This, no doubt, for a considerable period held a lake in the basin at the head of the river (the Morris Basin), but was eventually cut down to the level of the low part of the basin. From the Marseilles moraine westward the channel found no prominent drift barriers to remove, but has been compelled to cut down 50 to 75 feet into the rock in opening an outlet from the Morris Basin into the valley of the lower Illinois. The lower Illinois seems to have been so imperfectly filled by glacial deposits that throughout nearly its entire length the stream is reestablished in the old course. The valley of the lower Illinois ranges in width from $2 \frac{1}{2}$ to fully 15 miles. The narrowest portions of the lower valley are a short section at Peoria, where it passes through the Shelbyville morainic system, and a section embracing the lower $60 \mathrm{miles}$, where it traverses the Eocarboniferous and Silurian limestones. $a$

a Leverett, Frank: The Illinois glacial lobe. U. S. Geological Survey, mon. XxxvII. 
From its origin to Utica, a distance of about 43 miles, the river is a series of rock rapids and pools, and is practically destitute of mussels.

From Utica to Meredosia, a distance of 159 miles, the river flows through a region of but slight fall and abounds in sloughs, bays, lakes, islands, and drowned timber. The principal tributaries between these cities are the Vermilion, Mackinaw, Spoon, and Sangamon Rivers, the last-named of which produced some excellent shells this year. The river bottom of this stretch, with but few exceptions, is composed of mud or of mud and sand, which is characteristic to the mouth. From the mussel fisherman's point of view, the most important part of this section, as well as of the entire river, is Peoria Lake, which, by the dip-net method, has yielded many tons of good shells.

From Meredosia to Grafton, a distance of 71 miles, the river flows almost due south and rather close to the high bluffs on the right, except near the mouth, where it bears to the east and to the hills on the left. In this stretch there are fewer sloughs, but more islands and bars. In the vicinity of Hardin there are many productive mussel beds, with a yield second only to that of Peoria Lake.

\section{POLLUTION OF THE ILLINOIS RIVER.}

The effects of the sewage pollution of the Des Plaines River and the drainage canal upon the waters of the upper Illinois have been a subject for much discussion both to fishermen and the cities along the river. The analysis and general study of the physical conditions in the following data and tables were made under the direction of Prof. S. A. Forbes during the summer of 1911 and the spring of 1912:

During July the river between its origin and the Marseilles Dam is practically barren of fishes, bubbling with gases of decomposition, and full of floating organic matter, and the bottom is in many places deep with foul-smelling mud from which large bubbles of offensive gas escape when stirred. The character of the river changes greatly at this dam, black bass and carp coming up in some numbers to that point. During March, the organic matter of the sewage instead of being rapidly decomposed, with a nearly complete appropriation of the oxygen, as was the case last summer, is now being slowly decomposed, with a consequent gradual fall in dissolved oxygen, to Chillicothe, 93 miles down the river. At Morris there was 97 per cent of saturation in February, where last summer the average was less than 10 per cent, while at Chillicothe there is now 36 per cent where last summer there was an average of 44 per cent. Bottom conditions were similarly different. The gases of the bottom sediments at Morris last summer were largely methane, the product of organic decomposition in the absence of oxygen and the odor was that of a septic tank.

Table 1 shows the condition of the water during summer, Lake Michigan and the Kankakee River being high, while at the other places the percentage of saturation runs low. Table 2 shows the early spring conditions when the decomposition of organic matter $48718^{\circ}-14-2$ 
is very slow. Table 3 shows the percentage of carbon dioxide $\left(\mathrm{CO}_{2}\right)$, oxygen $(\mathrm{O})$, earbon monoxide $(\mathrm{CO})$, methane or marsh gas $\left(\mathrm{CH}_{4}\right)$, and nitrogen $(\mathrm{N})$ of the river and from septic tanks dusing the month of September.

Table 1.-Free Oxygen, Illinols Waters: Percentage of Saturation, July 18 to September 13, 1911.

\begin{tabular}{|c|c|c|}
\hline Lako Michigan. . ........................... & 95.5 & Starved Rock............. \\
\hline Kankakee River......................... & 112.3 & 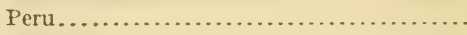 \\
\hline Des Plaines River... & 13.1 & 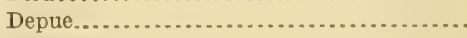 \\
\hline Morris........... & 9.8 & 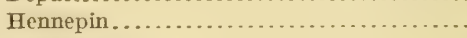 \\
\hline $\begin{array}{l}\text { Marseilles: } \\
\text { Above dam... }\end{array}$ & 7.5 & 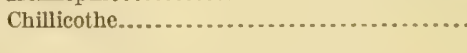 \\
\hline One-eighth mile below dam............... & 65.4 & \\
\hline Three-fourths mile below dam........... & 24.8 & \\
\hline
\end{tabular}

Table 2.-Dissolved Oxygen, Illinois River, March, 1912.

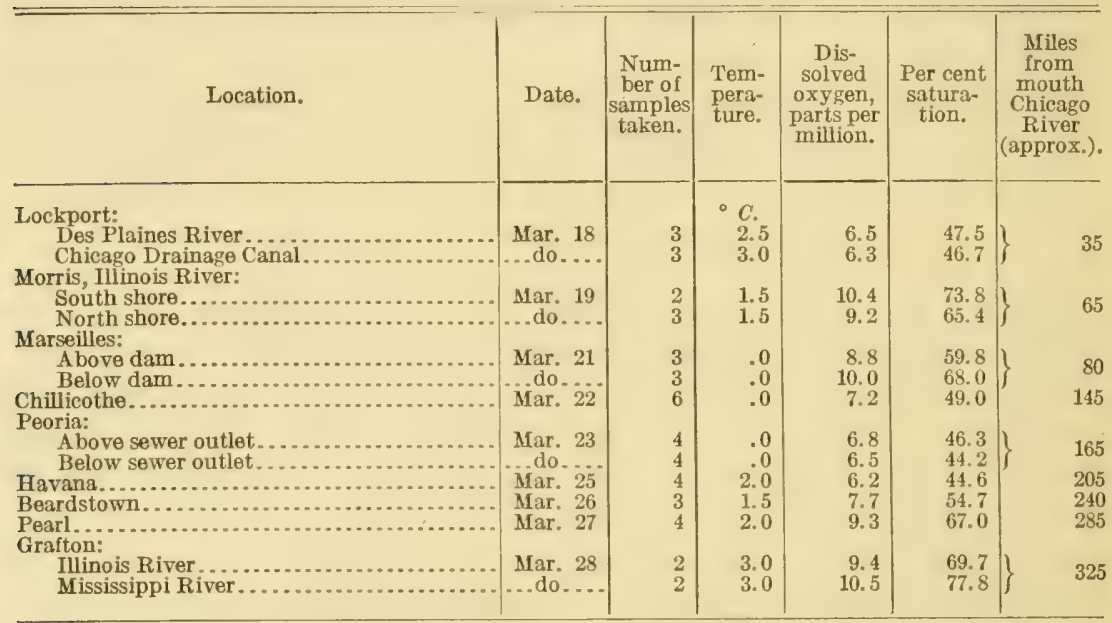

Table 3.-Gases from Bottom Sediments, Illinois River, and from Septic Tanks of Sewage Systems, September, 1911.

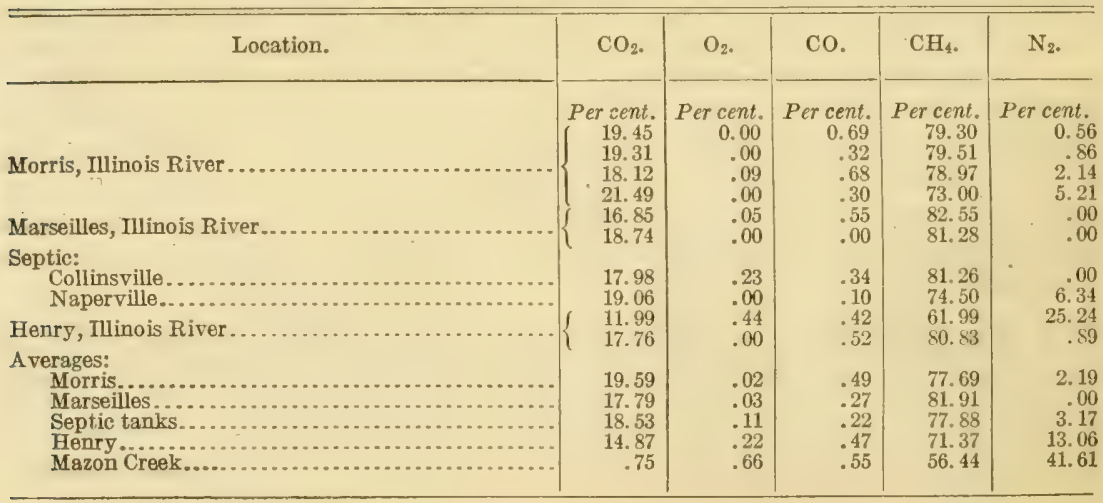


The following table, compiled from Water-Supply Paper 239, by W. D. Collins, ${ }^{a}$ gives the mean of 36 mineral analyses of water from the Illinois, Fox, and Sangamon Rivers. The analyses were made from August 1, 1906, to July 31, 1907. While the Illinois River water is not so high in carbonates, it is higher in sulphates and chlorine than other waters of the State. The Fox has a high percentage of magnesium.

Table 4.-Mineral Analyses of Water from Illinois, Fox, and Sangamon Rivers.

\begin{tabular}{|c|c|c|c|c|c|}
\hline & $\begin{array}{c}\text { Illinois } \\
\text { River, } \\
\text { La Salle. }\end{array}$ & $\begin{array}{l}\text { Illinois } \\
\text { River, } \\
\text { Peoria. }\end{array}$ & $\begin{array}{l}\text { Illinois } \\
\text { River, } \\
\text { Kamps- } \\
\text { ville. }\end{array}$ & $\begin{array}{c}\text { Fox } \\
\text { River, } \\
\text { Ottawa. }\end{array}$ & $\begin{array}{l}\text { Sangamon } \\
\text { River, } \\
\text { Spring. } \\
\text { field. }\end{array}$ \\
\hline & \multicolumn{5}{|c|}{ Parts per million. } \\
\hline 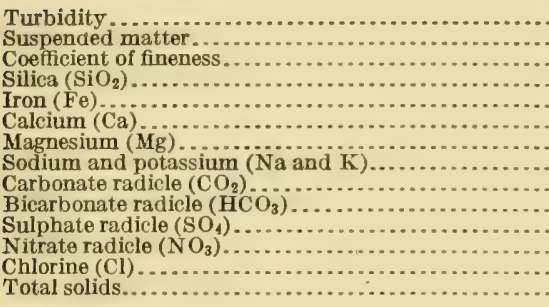 & $\begin{array}{l}159 \\
136 \\
12^{-8} \\
50^{\circ} \\
22 \\
16 \\
203^{0} \\
50 \\
6.6 \\
13 \\
278\end{array}$ & $\begin{array}{l}43 \\
26 \\
12^{\circ} \\
49^{\circ} \\
21 \\
17 \\
198^{\circ} \\
48^{7.8} \\
13 \\
271^{\circ}\end{array}$ & $\begin{array}{l}188 \\
145^{\circ} \\
47^{\circ} \\
20 \\
20 \\
202^{\circ} \\
42 \\
4.3 \\
15 \\
267\end{array}$ & $\begin{array}{l}94 \\
87 \\
1.2 \\
11 \\
60 \\
32 \\
14 \\
270 \\
275^{\circ} \\
61 \\
4.9 \\
7.9 \\
335\end{array}$ & $\begin{array}{c}74 \\
39 \\
16^{\circ} \\
52^{\circ} \\
52 \\
24 \\
16 \\
247^{\circ} \\
37 \\
3.4 \\
7.5 \\
276\end{array}$ \\
\hline
\end{tabular}

Whether or not the great amount of sewage that is annually poured into the river is detrimental to the aquatic life in the lower stretches, the fact remains that from Chillicothe to near the mouth, with few exceptions, the Illinois is indeed a wonderfully productive stream in fishes and mussels, and far exceeds in these resources many rivers not having similar physical conditions.

\section{THE MUSSEL INDUSTRY.}

It is of interest to note that probably the first American freshwater shells taken for the purposes of button manufacture were derived from the Illinois River. As early as 1872 a couple of tons of mussel shells were collected from the river at Peoria, Ill., and exported to Europe. Again from the same river, at Beardstown, Ill., in 1876, a shipment of shells was made to a New York firm for manufacturing purposes. In both cases the returns were evidently insufficient to warrant a continuation of the work, due largely no doubt to the want of machinery adapted to river shells, together with the general inappreciation of the value of the material. 
With the exception of a few pearl hunters making their test hauls and drifting at random along the different stretches, nothing of consequence was done in the shelling industry until the spring of 1892, when work began in earnest on a fairly large scale and continued all summer, at Meredosia. However, at the close of the season, the industry was apparently dropped on this river and practically nothing was done until 1907. At that time the supply of shells was diminishing greatly on the Wabash and some other streams, and it was feared that unless new territory should be found many of the shellers were liable to be out of employment and the button factories considerably hampered thereby. As the Illinois had been previously tested and proved satisfactory, the mussel fishermen from various localities went to that river in large numbers for shells and pearls. Shelling began at once in the Beardstown district, reaching from above Grand Island, and as far down as Pearl, and during the next two years the industry extended over the greater part of the stream. The Illinois reached its maximum shell production during the season of 1909, when thousands of tons of good button shells were gathered and put in piles along the shore to await shipment.

This river has been the most productive stream per mile of any in the country, and it has been reliably stated that only two or three years ago more than 2,600 boats were engaged in the mussel fishery between Peru and Grafton. It appears that the total number now engaged would not exceed 400 , and even this number is largely maintained by the new dip-net method in use at Peoria and the new field opened up in the lower district. For fishing to be profitable in a river like the Illinois, where the shells are not of the kind to command the highest prices, the yield must be relatively abundant. The price paid for the 1912 shells was from $\$ 12$ to $\$ 13$ per ton.

A button or blank factory was established on the Illinois at Beardstown in 1907, and the next year a second plant was located at Meredosia. At the present time (1912) along the river there are 15 factories with more than 250 machines, including 1 at Peoria, using about 4 tons of shells per week, 5 at Beardstown, 2 at Meredosia, 1 at Naples, 5 at Pearl, and 1 at Grafton.

Some of the earlier factories have changed hands a number of times; others have been dismantled and removed to other places. These factories are generally blank factories, sawing or cutting out the blanks which are sent elsewhere to be finished. The buildings are usually small frame structures, with inexpensive machinery.

CHARACTER OF THE SHELLS:

The Illinois is distinctively a washboard, blue point, and wartyback (Quadrula) river. The condition of the bottom, the current, and the general character of the river are well suited to the growth 
and development of these species, although several other genera occur in small quantities. The principal commercial species (which are found in larger numbers than all the other kinds combined) are the blue point $(Q$. undulata), washboard $(Q$. heros), warty-back $(Q$. pustulosa), three-ridge (Q. plicata), pig-toe (Q. undata), and muckets (L. ligamentina and Tuteola).

The Illinois River shells are generally perfect specimens, and seldom eroded at the beaks; and, for the class, the product is exceptionally good button material. A peculiar feature, however, of the shells, particularly noticeable in the lower stretches, is their gradual reduction in size as we go down the river. From the upper limits of shell production to Beardstown, the shells are of the average size of similar species found in other rivers of the Mississippi Basin, but from Beardstown to Hardin, a distance of 70 miles, they become gradually smaller, thence slightly larger to near the mouth at Grafton. Even old shells taken from protected places show this character. What causes this condition is not very evident. It can hardly be due to the lesser quantity of food material coming down the river from the drainage canal, or to any particular change of bottom. The quality of these smaller shells is fully as good if not better than those of the upper districts.

SCIENTIFIC AND COMMON NAMES.

The table of scientific and common names of the shells used in this report and given herewith is for the convenience of those who may desire to use the data for comparison. The nomenclature of Simpson, ${ }^{a}$ with but few exceptions, is used, although many of the recent changes recommended by Dr. Ortmann and others will doubtless prove to be well founded.

List of Common and Scientific Names.

Common name.

Scientific name.

Purple warty-back...................... Quadrula granifera (Lea).

Quadrula tuberculata (Raf.).

Niggerhead . . . . . . . . . . . . . . . . . . . Quadrula ebena (Lea).

Quadrula pyramidata (Lea).

Quadrula plena (Lea).

Quadrula solida (Lea).

Quadrula coccinea (Con.).

Ohio River pig-toe..................... Quadrula obliqua (Lam.).

Pig-toe. . . . . . . . . . . . . . . . . . . . . . Quadrula trigona (Lea).

Wabash pig-toe... . . . . . . . . . . . . . . . . Quadrula rubiginosa (Lea).

Two-horned pocketbook.................. Quadrula pustulata (Lea).

Warty-back....................... Quadrula pustulosa (Lea).

Quadrula fragosa (Con.).

a Simpson, Charles T.: Synopsis of the Naiades, or pearly fresh-water mussels. Proceedings U. S. National Museum, vol. xxI, no. 1205, 1900, p. 501-1044. 
Common name.

Scientific name.

Maple-leaf, stranger.................... . Quadrula lachrymosa (Lea).

Monkey-face. . . . . . . . . . . . . . . . . . . . . Quadrula metanevra (Raf.).

Washboard . . . . . . . . . . . . . . . . . . . . . Quadrula heros (Say).

Blue-point. . . . . . . . . . . . . . . . . . . . . . Quadrula undulata (Barnes).

Three-ridge. . . . . . . . . . . . . . . . . . . Quadrula plicata (Say).

Bull-head . . . . . . . . . . . . . . . . . . . . . . . Pleurobema æsopus (Green).

Elephant ear . . . . . . . . . . . . . . . . . . . . . Unio crassidens (Lea).

Lady-finger, spike. . . . . . . . . . . . . . . . . Unio gibbosus (Barnes).

Spectacle-case. . . . . . . . . . . . . . . . . . Margaritana monodonta (Say).

White heel-splitter. . . . . . . . . . . . . . . . . . . Symphynota complanata (Barnes).

Fluted shell . . . . . . . . . . . . . . . . . . . . . Symphynota costata (Raf.).

Rock-shell, bastard, queen . . . . . . . . . . . . . Arcidens confragosus (Say).

Anodonta corpulenta (Cooper).

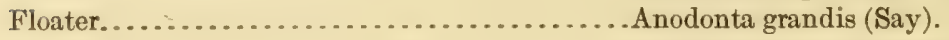

Anodonta suborbiculata (Say).

Anodonta imbicillis (Say).

Squaw-foot. . . . . . . . . . . . . . . . . . . Strophitus edentulus (Say).

Three-horned shell. . . . . . . . . . . . . . . . . . Obliquaria reflexa (Raf.).

Buck-horn, pistol-grip..... . . . . . . . . . . . . Tritogonia tuberculata (Barnes).

Little pocketbook....................... . . . . . . .

Deer-toe. . . . . . . . . . . . . . . . . . . . . . . Plagiola elegans (Lea).

Butterfly . . . . . . . . . . . . . . . . . . . . . . Plagiola securis (Lea).

Missouri niggerhead...................... . Obovaria ellipsis (Lea).

Paper-shell ............................. Lampsilis lævissima (Lea).

Lampsilis gracilis (Barnes).

Pink hatchet-back. . . . . . . . . . . . . . . Lampsilis alata (Say).

Lampsilis parva (Barnes).

Black sand-shell......................... . Lampsilis recta (Lam.).

Slough sand-shell. ...................... Lampsilis fallaciosa (Smith).

Yellow sand-shell ....................... . . . . . . .

Higgins-eye . . . . . . . . . . . . . . . . . . . . Lampsilis higginsii (Lea).

Lampsilis orbiculata (Hildreth).

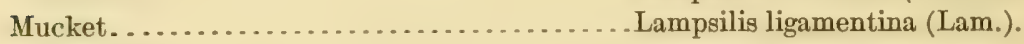

Fat mucket............................ Lampsilis luteola (Lam.).

Pocketbook. . . . . . . . . . . . . . . . . . . . . Lampsilis capax (Green).

Lampsilis ventricosa (Barnes).

\section{COMMERCIAL APPRAISAL OF QUANTITY OF SHELLS.}

The following table shows, in a general way, the number of shells to a given weight at four representative stations where the difference in size was very evident. The computation is based upon counts of 10 pounds of shells in each case, and the figures represent the number of pairs of shells. At Chillicothe the shells for the test were from a 65-ton pile; at Meredosia, from a 10-ton pile; at Florence, from a 16-ton pile; and at Hardin, from a 5-ton pile. The mixed shells were other commercial species taken from the same piles. The decrease in size between the shells from Chillicothe and those from Hardin is more than 50 per cent for the washboards and three-ridges, and slightly more than 25 per cent for the blue-points. 
Table 5.-Number of Shells of Different Species in 1 Ton at Four RepreSENTATive Stations.

\begin{tabular}{|c|c|c|c|c|}
\hline Species. & $\begin{array}{l}\text { Chilli- } \\
\text { cothe. }\end{array}$ & $\begin{array}{l}\text { Mere- } \\
\text { dosia. }\end{array}$ & Florence. & Hardin. \\
\hline 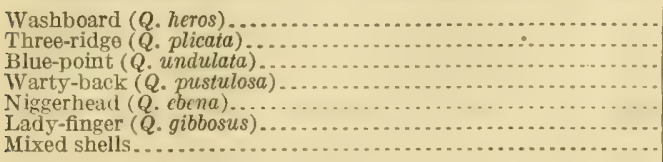 & $\begin{array}{r}2,000 \\
3,000 \\
6,800 \\
\ldots \ldots \\
\cdots\end{array}$ & $\begin{array}{r}2,400 \\
4,800 \\
7,000 \\
14,200 \\
10,800 \\
12,100\end{array}$ & $\begin{array}{r}3,400 \\
7,800 \\
77,200 \\
7,400 \\
\ldots\end{array}$ & $\begin{array}{r}4,800 \\
6,800 \\
9,200 \\
\ldots \ldots \\
\ldots \ldots \\
\ldots \ldots \\
21,200\end{array}$ \\
\hline
\end{tabular}

The following table of the commercial appraisal of the most important shells found by the author between Peoria Lake and Beardstown was prepared by Mr. J. B. Southall, shell expert of the United States biological station, at Fairport, Iowa. Samples of the different species were weighed, and from these there were cut blanks of 16 to 30 lines diameter. The number of gross of blanks per ton of shells was then calculated. $(\mathrm{L}=$ line $; 40$ lines $=$ an inch. $)$

Table 6.-Commercial Appraisal of Illinois River Shells.

\begin{tabular}{|c|c|c|c|c|}
\hline Species. & Locality. & Discoloration. & Luster. & Texture. \\
\hline 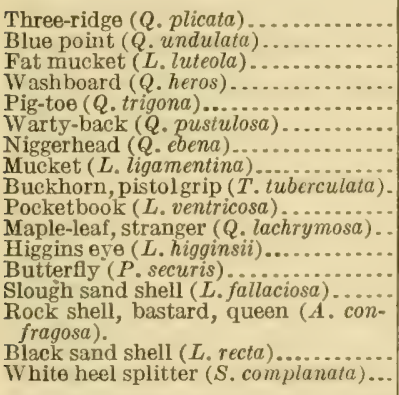 & 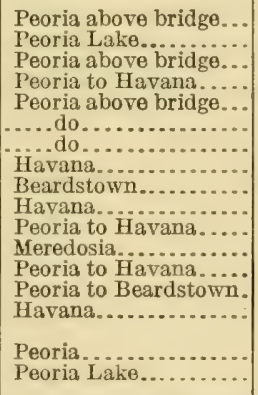 & 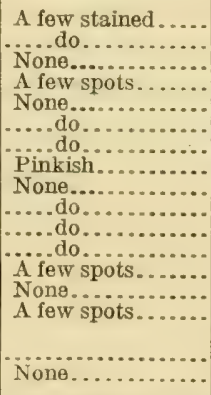 & 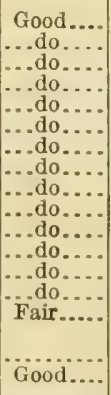 & $\begin{array}{l}2 \mathrm{~d} \text { grade. } \\
\text { 1st grade. } \\
\text { Do. } \\
\text { 2d grade. } \\
\text { 1st grade. } \\
\text { Do. } \\
\text { Do. } \\
\text { Do. } \\
\text { Do. } \\
\text { 2d grade. } \\
\text { 1st grade. } \\
\text { Do. } \\
\text { Do. } \\
\text { Do. } \\
\text { 2d grade. } \\
\text { 3d grade. }\end{array}$ \\
\hline
\end{tabular}

\begin{tabular}{|c|c|c|c|c|c|}
\hline \multirow{2}{*}{ Species. } & \multicolumn{4}{|c|}{$\begin{array}{l}\text { Gross blanks per ton } \\
\text { shells. }\end{array}$} & \multirow{2}{*}{ Remarks. } \\
\hline & $16 \mathrm{~L}$. & $20 \mathrm{~L}$. & $24 \mathrm{~L}$ & $30 \mathrm{~L}$. & \\
\hline 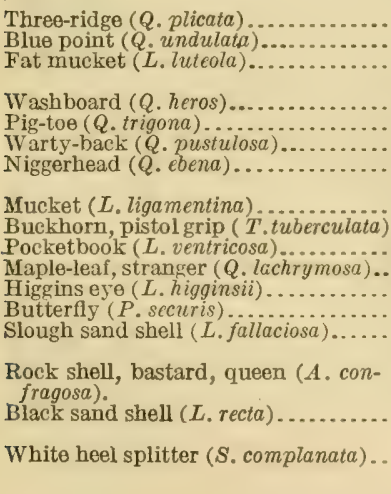 & $\begin{array}{r}\ldots 34 \\
700 \\
535 \\
\ldots \ldots \\
\cdots \ldots \\
\ldots \ldots\end{array}$ & $\begin{array}{c}424 \\
910 \\
1,278 \\
\cdots \\
874 \\
\cdots \\
256 \\
251 \\
\ldots \ldots \\
428\end{array}$ & $\begin{array}{c}480 \\
\ldots \ldots \\
\cdots \ldots \\
\cdots \ldots \\
\cdots \ldots \\
\cdots \ldots \\
\ldots\end{array}$ & $\begin{array}{c}\ldots \ldots \\
\cdots \ldots \\
326 \\
\cdots \ldots \\
\cdots \ldots\end{array}$ & $\begin{array}{l}\text { Medium to large, exterior not eroded. } \\
\text { Medium size, very good button shell. } \\
\text { Medium to large, smooth exterior, good } \\
\text { material. } \\
\text { Large, inclined to be a little chalky. } \\
\text { Medium to large and very thick beaks. } \\
\text { Large size, very good button material. } \\
\text { Large, fine luster, very fine button mate- } \\
\text { rial. } \\
\text { Large, one of the best button shells. } \\
\text { Very good button shell. } \\
\text { Large, inclined to be brittle. } \\
\text { Medium size, thick at beak, thin at tips. } \\
\text { Medium size, thick, good material. } \\
\text { Large, heavy, good material. } \\
\text { Small, good for novelties, large shells good } \\
\text { button material. } \\
\text { Large, heavy, fair button material. } \\
\text { Some white, some purple; good for nov- } \\
\text { elties. } \\
\text { About } 30 \text { per cent of shell good for but- } \\
\text { tons, remainder too thin. }\end{array}$ \\
\hline
\end{tabular}




\section{PRICES OF SHELLS.}

The price per ton of shells has varied to a considerable extent during the last few years on the Illinois, and also on different parts of the river, as well as on different rivers of the Mississippi Basin. The quality of the shells, transportation facilities, and the supply and demand are the principal determining factors. Only the very best grade of shells could find a market in 1902; all others were discarded, being left on shore and deemed entirely worthless. During the seasons of 1907 and 1908 the price ranged from $\$ 6$ to $\$ 20$, according to quality, and for the early season of the next year $\$ 9$ was paid for all grades, excepting culls, but near the latter part of the year the price went as high as $\$ 25$, which is about the maximum paid for the Illinois shells. The average price for 1912 was from $\$ 12$ to $\$ 13$ for the river run of marketable shells delivered on board the cars or on a barge at the river landing. There are so few niggerheads and yellow sand shells found on the Illinois that it is hardly profitable to sort them out, excepting in the lower stretch, where the percentage of the latter is large enough to do so. They then command a price from $\$ 50$ to $\$ 60$.

As shown by the following table taken from the United States Census Report for 1908, the mussel products of the Illinois River for that year constituted about one-sixth of the total value of the fishery products of this important stream; and, as stated on page 115 of the report, the yield of shells and pearls of this river was nearly 40 per cent of the total water product of the entire State.

Shells and pearls......................................... $\$ 139,000$

Carp................................................. 412,000

Other fishes.......................................... 309,000

Total...................................... 860,000

The report also furnishes the following information concerning the fisheries products of the Mississippi River and tributaries, 1908:

Shells and pearls................................... $\$ 686,000$

Other fisheries. . . . . . . . . . . . . . . . . . . . . . . . . 365,000

Total

$3,051,000$

Ratios of Illinois River to Mississippi and tributaries:

Shells and pearls................................... 20 per cent.

Other fisheries.................................... 30 per cent.

Fisheries products................................... 28 per cent.

Fisheries products, Illinois River, $1899 \ldots \ldots \ldots \ldots \ldots \ldots \ldots \ldots 24,000,000$ pounds.

Fisheries products, Illinois River, $1908 \ldots \ldots \ldots \ldots \ldots \ldots \ldots . . \ldots 6,000,000$ pounds.

Increase, 92 per cent.

The yield of one-fifth of the total amount of shells and pearls of the Mississippi Basin is indeed a remarkable output for one river the size of the Illinois. 
PRINCIPAL MUSSEL BEDS.

For convenience in dealing with the mussel fauna of the Illinois, the river may be divided into three sections:

1. The upper river, from the origin to Chillicothe, a distance of 93 miles.

2. Peoria Lake, from Chillicothe to Peoria, a distance of 20 miles.

3. The lower river, from Peoria to Grafton, a distance of 160 miles.

Upper river.-From its origin to Utica, a distance of about 43 miles, the river flows over a sandstone bed covered with large blocks of sandstone and bowlders. The water has a very decided odor, though it has been stated that in the low water of summer, before the opening of the drainage canal, the odor was more pronounced and disagreeable than at present. The rocks at the water's erge are corered with a slimy ooze having the same odor as the water. This portion of the river is more directly affected by the drainage canal than are the lower stretches. In the process of decomposition the organic matter of the sewage abstracts the dissolved oxygen of the water and renders it unfit for aquatic life. It is practically destitute of mussels and forms an impassable barrier for fish, at least during the summer months.

From Utica to Chillicothe, a distance of 50 miles, the shells are rather scattering and but little work is carried on. Occasional camps have been located at three or four points along this stretch, but the output was small. The commercial shells are mostly the three-ridge type, washboards, warty-backs, and muckets.

At La Salle the river is about a mile from the city. The right bank is low and inclined to be swampy; the left bank opposite the bridge is a fairly high range of drift material. The shore line on both sides is composed of mud with patches of sand and gravel. A peculiar slimy, tanky odor is noticeable at this point. No musseling is done, although a young man stated that last year he had done some pearling. According to his report, both the shells and pearls were very scarce.

At Hennepin there is a fairly good mussel bed; at Henry there are two, one above and the other below the dam; there is also a small bed on the right bank a quarter of a mile below the dam, but no shelling was being done on this bed.

The following table represents the percentages of the commercial shells from a 3 -ton pile at Henry:

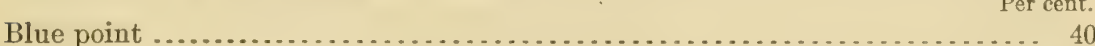

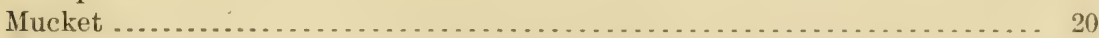

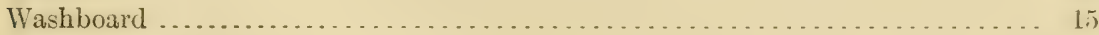

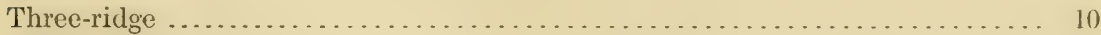

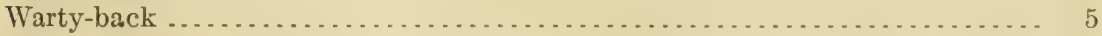

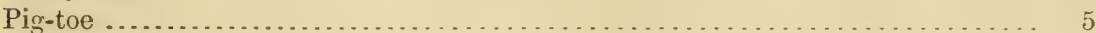

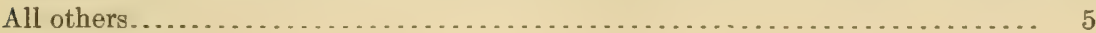

$48718^{\circ}-14-3$ 
The washboards are large, but badly spotted; the muckets and blue points have good luster and are good button shells.

At the present time it is a hard day's work to get 500 pounds of shells, while but a few years ago a man could dig a ton per day.

The bed above the dam has a depth of water from 10 to 20 feet and rather high mud banks. The current is about 2 miles per hour. An hour's work with bars and hooks on this bed yielded 128 shells, as follows:

\begin{tabular}{|c|c|c|}
\hline Blue point & 60 & Pink hatchet-back. \\
\hline Mucket ... . & 25 & Floater......... \\
\hline Three-ridge . & 10 & Buckhorn \\
\hline Warty-back & 5 & Slough sand-shell.. \\
\hline Pig-toe ...... & 5 & Deer-toe........ \\
\hline Washboard. & 4 & Squaw-foot. . \\
\hline Paper-shell. . & 4 & Lady-finger.. \\
\hline Maple-leaf... & 2 & \\
\hline ock-shell... & 2 & 1 \\
\hline White heel-s] & 2 & \\
\hline
\end{tabular}

There are a few small beds, 2 to 3 acres in extent, between Lacon and Chillicothe, yielding mostly washboards and three-ridges.

Peoria Lake.-From Chillicothe to Peoria, a distance of 20 miles, the river broadens into a lakelike expanse, called Peoria Lake, having a varying width of from a few hundred yards to nearly 2 miles. The slow current, the large volume of water, the good average depth and soft mud bottom are suitable for mussel growth, and there are consequently many fine mussel beds and an enormous quantity of shells, making this at present probably one of the best musselproducing districts in the United States. Although the bottom is covered with dead shells, there have been taken, during the latter part of 1911 and the season of 1912, many tons of good shells by the lately devised dip-net method. Just what has caused the mortality of so many shells at this point and elsewhere on the river is not known. When the dip-net is brought up and the catch is emptied into the boat, the shells are sorted, the dead ones being thrown back into the river, thus keeping the bottom continually covered with them.

It is difficult to state where the mussel beds are located in Peoria Lake; in fact, they appear to be pretty well distributed over the entire bottom. Certain localities, however, are much more productive, while they vary to a considerable extent in abundance of species.

At Chillicothe there was on shore a 65 -ton pile of shells, taken from the local beds, with the following percentages: Blue points 50 per cent, washboards 25 per cent, mixed shells 25 per cent, the latter consisting mostly of three-ridges, muckets, warty-backs, pig-toes, slough sand-shells, and rock-shells. On the entire pile not more than two or three niggerheads were seen. The washboards were tolerably 
spotterl, but hardly so much as at Henry; the blue points were rather small and thin posteriorly.

There is a good bed, extending from a mile above the railroad bridge to 300 yards below, having a width nearly that of the river. The current is about 2 miles per hour; the bottom clay and sand; the banks low on both sides, and the depth of the water 12 to 15 feet. The following is the result of a two-bar haul over the lower end of this bed:

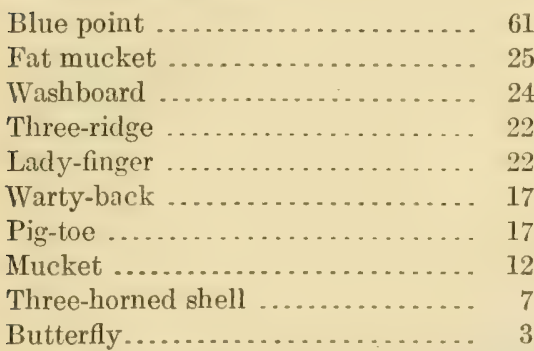

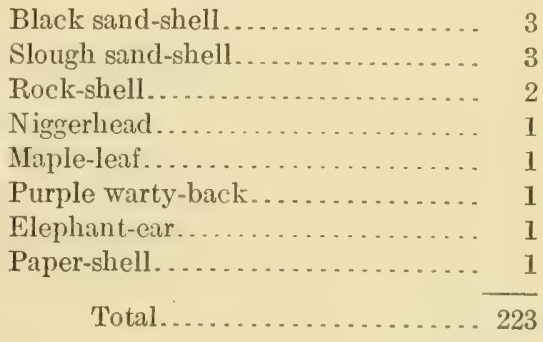

Formerly niggerheads would average 10 to 12 per haul, but now only an occasional one is found. This bed does fairly well on rising water, yielding about 500 per day.

Opposite and extending below Chillicothe, there is a small bed, 100 yards by one-half mile, but it was not being worked much this year. During 1911 a $\$ 3,000$ pearl was found at this place.

A mile above Rome there is a good mussel bed, but as it is full of hang-ups, little shelling was done. We lost our bar on the first haul and were compelled to abandon this place. Just below, another good bed, one-fourth by 1 mile, yields mostly washboards and blue points.

There is also a fine little bed, 25 feet by 300 yards, 1 mile below Rome, but since it has scarcely been touched, it is covered with trash and water plants. The yield is largely blue points and three-ridges.

At Sand Beach Bar, a mile above Spring Bay, there is a small bed, 200 yards by one-fourth mile. The bottom is composed of soft mud, with some sand and many dead shells. A series of dip-net hauls showed but a small percentage of sheils, mostly blue points and pigtoes. On account of the dams and the excess of water from the drainage canal, this bar is covered by water the entire year. On many low points and banks there is considerable drowned timber, due to the same cause.

There is an excellent bed, one-fourth by $1 \frac{1}{2}$ miles, at the narrows below Spring Bay. The bottom is soft mud, clay, and dead shells; depth of water 8 to 10 feet; fair current. A comparison of two hauls, one made with an ordinary mussel bar of 98 hooks, distance 50 yards, and the other with an 18-inch dip net, 50-yard circle, is given in table 7 . 
The bar caught 136 shells of 11 species; with the dip net the result was 74 live shells of 18 species. The first, however, produced nearly twice the number of commercial shells, but it took more than twice the time to make the haul; also the shells had to be taken one by one from the hooks, while the dip net was dumped at once into the boat, and the trash and dead shells were thrown back.

Mr. Oscar Nash, who assisted in the work on this bed, stated that in 1909 he obtained here 14 tons in 17 days and sold them for $\$ 18$ per ton.

Table 7.-Comparison of Hauls Made with the Dip Net and the Mussel Bars.

\begin{tabular}{|c|c|c|c|c|c|}
\hline \multirow{2}{*}{ Species. } & \multicolumn{2}{|c|}{ Number of shells. } & \multirow{2}{*}{ Species } & \multicolumn{2}{|c|}{ Number of shells. } \\
\hline & Dip net. & Bar. & & Dip net. & Bar. \\
\hline \multirow{9}{*}{ 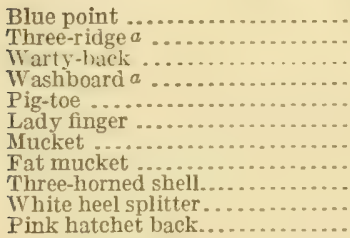 } & 44 & \multirow{9}{*}{$\begin{array}{r}102 \\
15 \\
3 \\
1 \\
6 \\
2 \\
2 \\
\cdots \\
2 \\
1\end{array}$} & \multirow{9}{*}{ 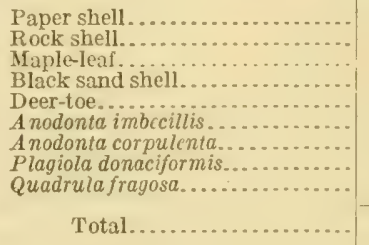 } & 1 & \\
\hline & 3 & & & 2 & \\
\hline & 1 & & & 1 & \\
\hline & 1 & & & 1 & \\
\hline & 1 & & & 2 & \\
\hline & 4 & & & $\begin{array}{l}1 \\
1\end{array}$ & \\
\hline & 1 & & & 1 & \\
\hline & 6 & & & 1 & \\
\hline & 2 & & & 74 & 136 \\
\hline
\end{tabular}

$a$ The washboards and three-ridges are found mostly in the channel.

On the Mossville Flats, just below the narrows, there were four camps in operation, and about 30 tons of good shells, largely blue points, and muckets, with fewer washboards, and some pig-tocs. The washboards are very good and but little spotted. In this vicinity one man with a dip net can dig 1,000 to 1,200 pounds in half a day. It is claimed that some beds here have not been even touched.

At the present time Peoria is a great center of shell production. During the mussel-fishing season men from various parts of the river go there fully equipped to work, as the dip net can be used advantageously and the yield is exceptionally good. There were many camps at Gatlin's landing and from 80 to 100 tons of shells on strore. A similar condition exists just above this place, at Averyville. One shell buyer stated that he had purchased 600 tons at these two places last year and would at least equal it this season.

The percentages of the different species of the different camps vary considerably according to the part of the lake fished. One camp of six to eight tons had the following percentages of shells:

Per cent.

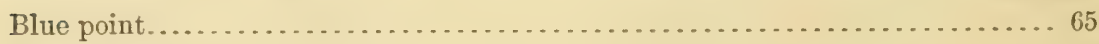

Three-ridge .................................................... 15

Mucket..................................................... 7

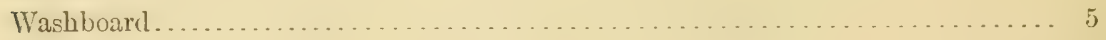

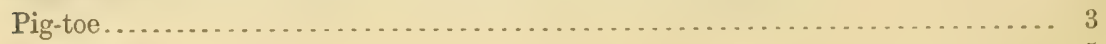

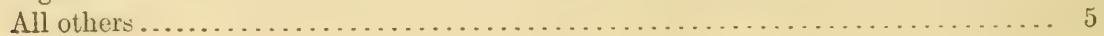


The shells grouped under "All others" include white heel splitters, slough sand shells, etc.

The bed just above the upper bridge at Pcoria was examined. On account of the bottom not being suitable for the dip net, the ordinary bars were used. Thirty species were found, the percentages of commercial shells of which are as follows:

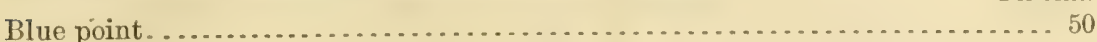

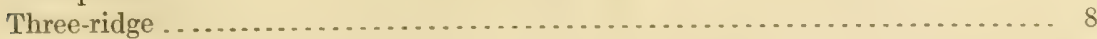

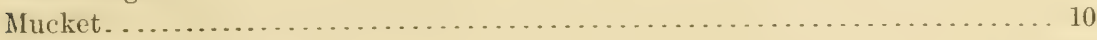

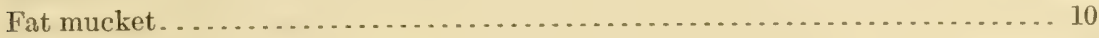

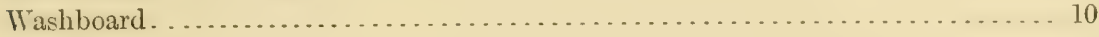

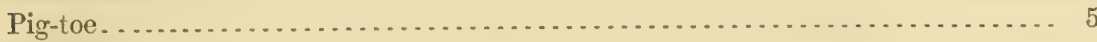

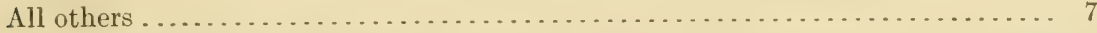

A day's work, including cooking, will produce 700 pounds of shells from this bed. When the dip net and a good gasoline boat are used on favorable bottoms much better results are obtained.

Lower river. - That part of the Illinois from Peoria to Grafton may, for the purposes of this discussion, be designated as the lower river, which is conveniently divided into two sections, the first from Peoria to Kampsville and the second from the latter place to the mouth.

First section: Between Peoria and the Government Locks at Kampsville, a distance of 128 miles, the mussel supply is very poor as compared with the output of two or three years ago. Although many tons of good shells are still being taken, the river shows marks of depletion.

There are five tolerably well-established beds between Peoria and Pekin, but they were not worked to any extent during the present season, probably on account of the nearness of Peoria Lake and the better results obtained in that region, where the dip net is used to good advantage. In 1910 there were 25 shellers at work on these beds, 10 in 1911, and but 1 or 2 in 1912. The first bed below Peoria extends from Kickapoo Point to Wesley; the second from Willow Point to within one-half mile above Seven-Mile Island; the third from the foot of this island and extending down $1 \frac{1}{2}$ miles; the fourth from the river road to within three-quarters of a mile of the bridge at Pekin; and the fifth from the "day mark" to the bridge at Pekin, a distance of one-haif mile. ${ }^{a}$ During the early part of this season (1912), Mr. Lemm gathered from these beds about 10 tons of good shells, of which 60 per cent were blue points, 25 per cent washboards, 10 per cent three-ridges, and all others 5 per cent. The washboards were exceptionally good.

Although there are several good mussel beds between Pekin and Havana, but little shelling has been done. The bottom is composed

\footnotetext{
a Mr. Herman Lemm, of Pekin, Ill, furnished the information concerning the location of these beds.
} 
of mud and sand, covered more or less with dead shells and trash. At the mouth of Mackinaw River the bottom was soft mud and practically without mussels. The water had a very bad odor, due to sewage pollution. In reference to the soft-mud bottoms, Mr. Freeland states: "I jumped from the front end of a launch near Copperas Creek Locks and sank into the mud almost to my hips. At the mouth of Old Crow Creek at Chillicothe, at the mouth of the Mackinaw River below Pekin, above Copperas Creek Locks and Dam at Liverpool, and in the narrow reach between Liverpool and Havana this condition exists, not only near the shore, but all the way across the river. At Liverpool the weight on the sounding line sank into the mud at the middle of the river when attempts were made to ascertain water depths." The percentages of shells of this stretch are about as follows:

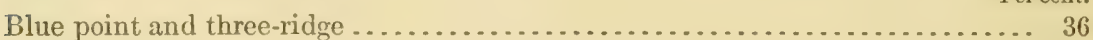

Warty-back ................................................... 30

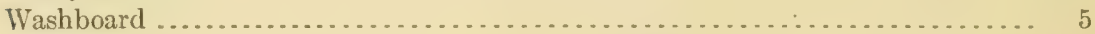

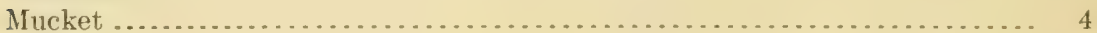

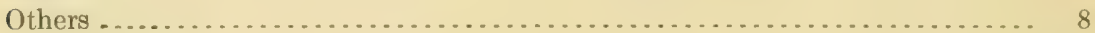

Noncommercial............................................. 17

At Havana there were five or six camps with about 30 tons of good shells, which were taken mostly from the beds below the city where the washboards predominate. The percentages of shells are about as follows:

Per cent.

Washboard .................................................... 50

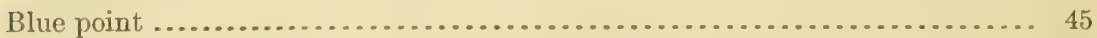

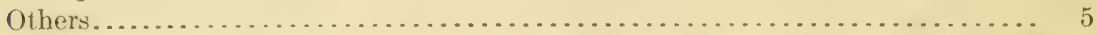

The mixed shells were the black sand shells (some of which had a white nacre, others being deeply colored), yellow sand shells, wartybacks, pig-toes, buckhorns, rock shells, higgins eyes, deer-toes, and pocketbooks.

In company with Mr. Henry C. Allen we examined the beds in the vicinity of Havana with the dip net. Above the mouth of Spoon River a small bed 2 to 3 acres in extent is fairly productive. The bottom is mud, there is a 2 -mile current, and the depth of the water is 8 feet. Several hauls were made, showing 75 per cent of blue points and 17 per cent of noncommercial shells. There were also many dead shells.

Another bed, with the same bottom conditions, but with many more dead shells-especially noticeable in the older washboards-and thousands of live snails, is located at the head of Cooks Island. The percentage of this bed is: Blue points, 35 ; three-ridges, 24; wartybacks, 12 ; rock shells, 8 ; maple leaves, 7 ; slough sand shells, 7 ; washboards, 4 ; and others, 3 . 
The bed at the mouth of Quiver Lake showed that fully 90 per cent of the shells were dead. The only live ones found were of the threeridge type and small washboards, 2 to $2 \frac{1}{2}$ inches in length. It is difficult to state just what has killed the shells at this point, although the young washboards, 2 to 3 years old, were strong and vigorous, indicating that more favorable conditions exist at present. The east shore, especially on the lower course of the lake, is sandy, and on digging a few inches into the sand clear, cold water was found, coming from the uplands. The west shore is low, and since the building of the drainage canal all kinds of timber on overflowed lands-acres upon acres-have been killed, due to high water the entire year.

A small bed of the three-ridge and floater types extends from Cooks Island to the railroad piers. The depth of the water is 8 to 20 feet and there is a fair current. This bed, especially on the lower end, has a very poor output.

Formerly the mussel beds in the vicinity of Bath were perhaps the most productive ones of the entire river. Hundreds of tons of good shells were gathered and shipped from there. The industry, however, has dwindled to such an extent that at the present time there are only six camps in operation, with about 50 tons on shore.

The beds above Grand Island, though fairly productive, could be restored to a considerable extent by propagation.- The bottom is of hard mud, the current is fair, and the shores are low mud banks sovered more or less with timber. In testing these beds, as well as those down the right chute of the island, two bars of 90 hooks each, were used. These beds gave the following percentages of shells:

Percent.

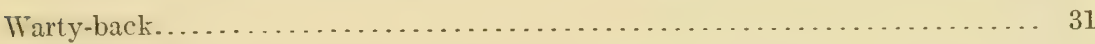

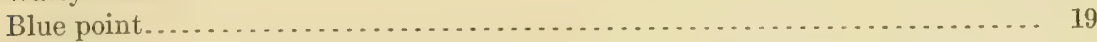

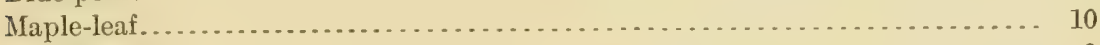

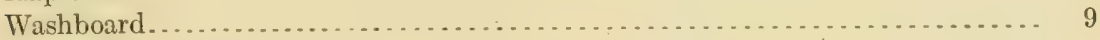

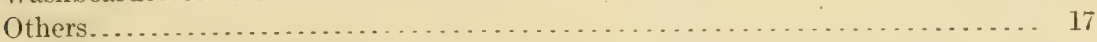

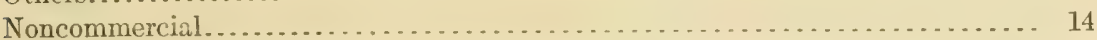

In the right chute, the conditions are somewhat better, though there are more trash, hang-ups, and dead shells. About halfway down, the bottom for a short distance is mostly sand and as a consequence the epidermis of the shells is inclined to be yellowish. A washboard, conspicuous by having a pronounced ridge and valley running diagonally from the umbone toward the posterior end was taken in one of these hauls. On opening the shell, the mantle at the tip contained a 10-grain hightop pearl of good luster, but badly discolored on the base. These beds had warty-backs, 38 per cent: blue point, 16 per cent; washboards, 11 per cent; other commercial shells, 15 per cent; and noncommercial shells, 20 per cent. 
Matanzas Bay, above Bath, is being worked with dip nets. Ninety per cent of the commercial shells are blue-points. There are, however, many paper-shells and Anodontas, and many dead shells.

The beds at Beardstown have been extensively worked, and though fairly productive, 500 pounds of shells per day of 10 hours' labor with a gasoline boat is considered a good catch. Fifteen to twenty boats were working there, and the five button factories use the shells of the locality. Although the output is not good, there are three reasons why these beds are being so heavily worked, namely, the fair amount of pearl finds, the nearness to home, and the ready market.

An estimation of percentages from a 25-ton pile of freshly dug shells shows washboards, 35 per cent; blue-points, 24 per cent; wartybacks, 18 per cent; three-ridges, 8 per cent; all others, 15 per cent. Though smaller than the same species above Beardstown, the washboards are exceptionally good in this pile.

A series of test hauls of 200 yards each were made with the mussel bar on the 5 -mile bed at Beardstown, beginning above the railroad bridge and extending 1 mile below. The bottom is sand and mud; the depth in channel, 10 to 20 feet; there is a 2 -mile current, and the banks are low. This bed has washboards, 25 per cent; warty-backs, 19 per cent; blue-points, 11 per cent; pig-toes, 10 per cent; others, 12 per cent; and -noncommercial shells, 23 per cent.

On the right bank below the bridge the washboards are more abundant, but, owing to so many snags and hang-ups, it is deemed inadvisable to work at that point. The niggerheads are scarce, though they are reported to have been plentiful some years ago. The spikes or lady-fingers are abundant. The washboards are but little spotted and are good button shells.

In the bay above Beardstown the washboards are more spotted and not so desirable for commercial purposes.

Three miles above La Grange Locks there is a small bed, one-half mile in length and practically as wide as the river, excepting in the channel. The river conditions are as follows: Current, 1 mile; 8 to 12 feet deep; mud bottom. On this bed the washboards are nearer to the shore, while the smaller shells are farther out. This and the two beds just below yield about 200 pounds per day, with bar. Very few pearls and slugs are found. The percentages of commercial species of these beds were determined from camps situated 3, 2, and 1 miles respectively, above the locks: washboards, 50 per cent; blue points, 20 per cent; three-ridges, 10 per cent; wartybacks, 10 per cent; and others, 10 per cent. 'The washboards are very good.

A bed beginning a little below the locks and extending to Meredosia, although fairly productive, was being fished but very little. The shells are pretty well distributed, except in the channel. The river 
conditions at this point are: Slow current; 8 to 15 feet deep; and bottom of clay, mud, and sand. The pocketbooks, pig-toes, and purple warty-backs were somewhat more abundant than in the preceding beds. It was stated that some years ago the niggerheads, yellow sand shells, and muckets were plentiful. There is a large percentage of lady-fingers, which when eaught are generally thrown back into the river.

At Meredosia the mussel fishermen were discouraged and stated that "the river is playing out." Several camps were considering the advisability of moving to more favorable localities, either on the Illinois or Mississippi. Although the output-200 to 300 pounds of shells per day-was small, the number of good pearl finds afforded considerable stimulation to the work. During 1909 there were 200 men at work between Meredosia and Naples, and they gathered 100 carloads, the price being $\$ 25$ a ton, ${ }^{a}$ while in 1912 there were but 25 to 35 men gathering 15 carloads at $\$ 13$ per ton. There were about 400 tons in the hands of the buyers and 250 tons at the two button factories. In this stretch of the river the niggerheads and muckets are scarce, but there is an abundance of lady-finger's. The washboards here, being clear of spots, are the best button material, and the next best are the blue points and warty-backs. The few niggerheads found are thin.

'At Valley City there were 10 to 12 men working on the local beds, the output not exceeding 300 pounds. It was stated that there were many boats employed here last summer. There is a small bed, 300 to 400 yards long, situated on the left bank, one-eighth mile above the railroad bridge. This bed is covered more or less with trash and hang-ups, thereby making it remarkably interesting, in that it is practically in its native state. It contains 18 species of commercial shells, including a fair percentage of niggerheads, pocketbooks, and muckets.

Although early in the season, 40 men were fishing on the mussel beds in the vicinity of Florence, while but 9 were engaged in July. Forty tons of 1912 shells had already been shipped and half that amount were on shore. The following percentages were determined from a number of hauls made at Florence, two bars of 100 hooks each being used; the bottom, sand and mud with brush and dead shells.

Per cent.

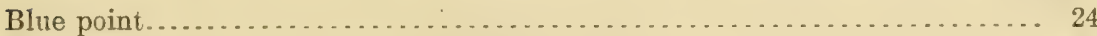

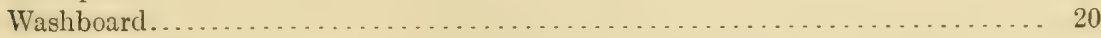

Warty-back . . . . . . . . . . . . . . . . . . . . . . . . 18

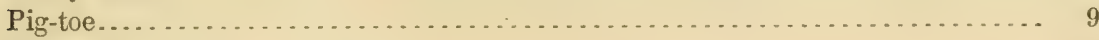

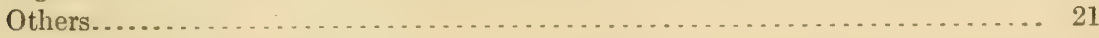

Noncommercial. . . . . . . . . . . . . . . . . . . . . . . . 
Only one each of elephant-ear and squaw-foot were found; the lady-fingers were smaller and much less abundant than at Meredosia and Valley City. This bed will yield 200 to 300 pounds per day per man.

There are good beds on both sides of the river practically all the way from Florence to Montezuma. At the latter place, 12 tons of shells had been shipped this year, and 5 tons remained on shore. There were two to four men working on the mussel beds, getting 200 to 300 pounds per day. It was stated that two years ago there were 30 to 40 boats in operation, and 200 tons were shipped. The percentages of the shells are about as at Florence.

From Bedford 15 to 20 tons had been shipped by the middle of July and 8 tons were on shore. There were 10 boats at work, the yield being 300 to 400 pounds. The shells are the usual run, however, some beds have as much as 5 per cent of muckets, while on others the lady-fingers appear to be associated with the washboards.

A few years ago Pearl, like Bath, was a great mussel center. Then there were 300 to 400 men working on the bed, beginning near Bedford and extending in zigzag lines for 15 miles down the channel of the river. At the present time (1912) there are 30 men engaged in the mussel fishery, and they have gathered 10 to 12 carloads of good commercial shells; but the conditions have so changed and the outlook is so unfarorable that some of the local button factories are anxious for new territory.

Near shore, in the left chute at the foot of Spar Island, 3 miles below Pearl, there is a good productive bed yielding mostly rather large washboards, a fair percentage of blue points, and a few muckets. This bed has a mud bottom somewhat covered with trash, and is best worked by wading and diving. Near the shore line fully 75 per cent of the shells were slough sand shells, burrowed in the mud and standing on end.

The camps at Gravel Point, Webbs Landing, and Woods Creek Landing had 15 boats in operation, with an output of 30 tons. The shells in this stretch are of the usual run, though there is a smaller percentage of culls, such as lady-fingers and paper shells. The washboards are exceptionally good. 
Table 8.-Percentages of Different Species of Mussels at Six Stations in the Lower Stretches of the River.

Species. $\ldots \ldots$
$\ldots$

Note. $-X$ represents less than 1 per cent.

Second section: From Kampsville to the mouth of the Illinois at Grafton, a distance of 32 miles, the mussel conditions are much better, and the rirer is yielding greater quantities of shells than any other portion except the Peoria Lake region. There were about 150 boats at work in this stretch, with a daily yield of 500 to 700 pounds of shells per man.

Except in the last few miles of the lower course, the river bears closely to the right of the watershed and to the high bluff's and wooded hills, and consequently becomes very picturesque in appearance.

Above the Government locks at Kampsville 10 men were engaged in mussel fishing, each obtaining 300 to 500 pounds per day. There were 30 tons on shore. The last bed above the locks extends almost to the dam and is more productive on the lower end, probably due to the fact that but little work had been done there on account of the danger. The beds produce washboards, 45 per cent; blue points, 21 per cent; warty-backs, 20 per cent; while just below the dam the yield is not so large, yet the pearl finds will probably more than make up the difference.

Below the Kampsville locks (the last in the river) the water is swifter, and the stream is in its natural condition. The shells are about the same as above, but near the dam there are more pocketbooks (L. ventricosa and capax) and fat muckets. Some beds also have a large percentage of lady-fingers. On July 3 a sheller working the bed below the locks unguardedly ran his boat into the falls of the dam and was drowned.

From Willow Island to the foot of Hurricane Island there were 30 boats in operation, and very good results were obtained. Both sides of the latter island have good productive beds; the catch, 
especially in the channel, is: Washboards, 75 per cent; blue points, 10 per cent; and warty-backs, 10 per cent. A good 32-grain pearl was found in this stretch during the summer.

There were four camps and 26 tons of shells on shore in the dark or right chute of Diamond Island. This chute is deep, narrow, and has a number of hang-ups. No shelling is done here on Mondays on account of the large steamboat which makes a round trip then from St. Louis to Kampsrille. In going through this chute the steamboat makes such large and dangerous wares that no small craft there could keep from sinking. Twenty-eight species in all were taken here, including the only spectacle-case ( $M$. monodonta) taken during the entire trip. The shells are largely washboards of cxcellent quality, and but few lady-fingers. The bed affords 400 to 600 pounds per day per man. The left or light chute is much shallower and the beds have a good yield of commercial shells.

At Hardin there were from 60 to 100 gasoline boats at work on the mussel beds, the yield being from 400 to 700 pounds of good quality shells. Probably by the latter part of July as many as 1,000 tons had been shipped from there, about one-third of the amount going 10 Canadian factories. It appears that Hardin would be an excellent location for a button factory, the raw material being so abundant and near at hand. A number of good pearls were found this year, the most valuable one selling for $\$ 750$.

A series of test hauls were made, beginning at the foot of Diamond Island and extending to Hardin. The mussel bar and crow-foot hooks were used. From this bed 34 species were taken, also a number of dead shells. The percentage was:

Washboard............................................. 23

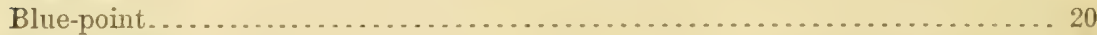

Warty-back ......................................... 13

Three ridge................................................ 11

Niggerhead............................................... 4

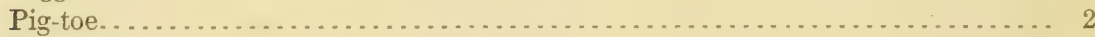

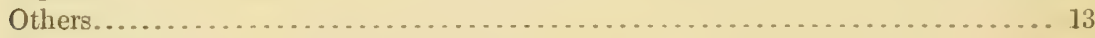

Noncommercial............................................... 14

In that part of the Illinois from Hardin to Grafton at the mouth, a distance of 20 miles, there are practically no places for accommodations in the way of lodging, and it was necessary to make the surrey of the interesting district in one continuous run, from early morning until late at night. There are a number of good and productive mussel beds in this region, with the exception of the last few miles of the river.

In the left chute of Mortland Island the yield of shells is 400 to 600 pounds per man per day. There are 12 to 15 camps within 2 miles of each other, and 90 to 100 tons have been taken this year. The shells are of the usual run of those found in this stretch, though the 
washboards are rery small and there are ferrer culls, such as ladyfingers.

At Twelve-mile Island there were four camps in operation, two on each side of the island, the average daily yield being from 400 to 600 pounds per man. Early in the season the upper camp of the right chute took 1,200 to 1,800 pounds per day, which was very good work indeed with the mussel bar and crow-foot hooks. The lower camps, during the earlier part of the season were overflowed, and work accordingly could not be carried on; however, when the conditions became more favorable, two men gathered 30 tons of good marketable shells in eight weeks. The mussel beds in the vicinity of this island produce about 65 per cent of washboards, 20 per cent of the three-ridge type, a very small percentage of niggerheads, and a sufficient quantity of yellow sand-shells to be sorted out and sold separately at an advanced price of from $\$ 50$ to $\$ 60$ per ton. The lady-fingers and other noncommercial shells are not very plentiful in this district.

In the last productive stretch of the river there are 10 to 15 mussel camps in operation, the daily output being 500 to 600 pounds, which is somewhat less than the immediate shelling districts above. The shells of the three-ridge type are more abundant, though there are fewer warty-backs; the washboards have again become a trifle larger than at Hardin, but they are not quite so good from a commercial standpoint, as they are inclined to be spotted.

As a comparison of the Illinois River product with that of the Mississippi, the percentages given in the brief table below were made from a 2-ton pile of recently gathered shells taken in the Mlississippi at Grafton, just below the mouth of the Illinois. It will be observed that the niggerheads are relatively abundant and that there is a fair amount of yellow sand-shells.

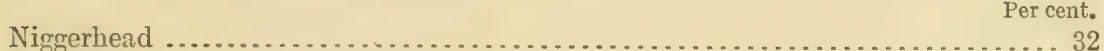

Blue point. . . . . . . . . . . . . . . . . . . . . . . . . . . . . . . 20

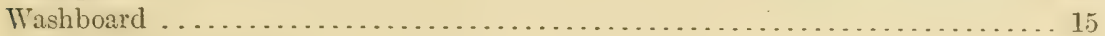

Yellow sand-shell ............................................ 7

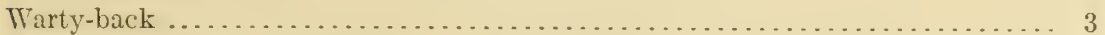

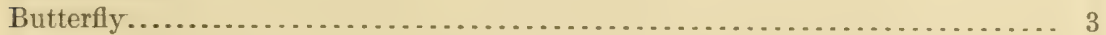

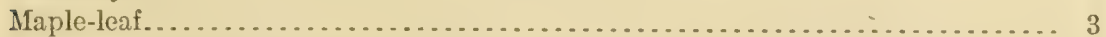

Others, including culls, etc..................................... 17

Tributaries.-The tributaries of the Illinois, as a rule, produce a superior grade of shells and a larger per cent of pearls and slugs than the main stream. A serious disadvantage, however, of the smaller rivers is that, especially during the low water of summer, the mussel beds are liable to be almost completely depleted by waders, either pearlers or shellers.

Spoon River.-No extended investigations were conducted on the Spoon River during the present survey; however, a short trip was 
made in the lower stretches, which did not revenl very satisfactory conditions for mussel beds. The banks are composed of drift or mud, and the low bottoms are subject to overflow in times of high water. The river is very crooked, with numerous large bends and a considerable number of cuts and corresponding fills and bars on the opposite side. It is practically a depleted stream, as relates to the mussel fishery, though the upper portions are more favorable for mussel beds, and it is a question whether it would be profitable to restock it or carry on propagation work to any extent, as it is so readily exhausted in a season or two by pearl hunters and others.

There have been recorded, 20 years ago, from the Spoon River, about 38 species of the Unionidx. ${ }^{a}$ The commercial species listed in the general table of species on page 37 were from a pearl hunter's pile of shells taken from the upper river during the present season. The shells were excellent in quality, and large in comparison with those of the Illinois. Some of the washboards (Q. heros) were so large that they would hardly fit into an ordinary hat.

Sangamon River.- The Sangamon River is about 170 miles in length and has a drainage basin of 5,670 square miles, which is the largest of the tributaries. The lower stretch, formerly very winding and overflowing the lowlands, has been straightened by means of a diteh.

The general conditions of this river, with its many favorable places for beds, are good for mussel development, and the propagation of the better species could be easily carried on and the river mado to yield a reasonable annual return, provided it were judiciously fished. $\Lambda$ station was made near Springfield, Ill., and the commercial shells found there are lister on page 37 . The shells are of a better grade than those of the main stream, and the muckets, niggerheads, and buckhorns are more abundant. About 100 tons of good shells have been gathered this year, with a daily output of 400 to 500 pounds. A number of fine pearls and slugs were found, and all were generally of a rather good grade. The river appears to be fairly well cleaned out.

\section{DEAD MUSSEL BEDS.}

At several places on the Illinois, more particularly noticeable in the lower stretches, there are evidences here and there of old covered-up mussel beds which lie several feet below the surface. The keeper of the Government locks at La Grange stated that at the time of building the locks, when extensive excaration was done, a dead mussel bed of some extent and thickness was cncountered at a short distance below the present surface, and that the shells were lying in their natural position.

a Strode, W. S., MI. D.: The Unionidæe of Spoon River, Fulton County, Ill. The American Naturalist, vol. Xxvi, 1392, p. 495-501. 
Near the head of Diamond Island, situated about 2 miles above Hardin, there is exposed at low stages of the river along the shore line from below the water's edge to a foot above, an extensive bed of dead shells, as shown at $\mathrm{A}$ in figure 1. A similar condition exists further down the river on the right bank, as shown at B in figure 1. This is probably a continuation of the same bed. Below Hardin two additional beds are exposed where the current has undermined and cut away the banks-one bed at the head of Mortland Island extending irregularly down the left chute of the island for half a mile, and the other at the head of Twelve-mile Island.

Here, no doubt, is a situation of the destruction of large mussel beds in comparatively recent times by means of a silting or filling in

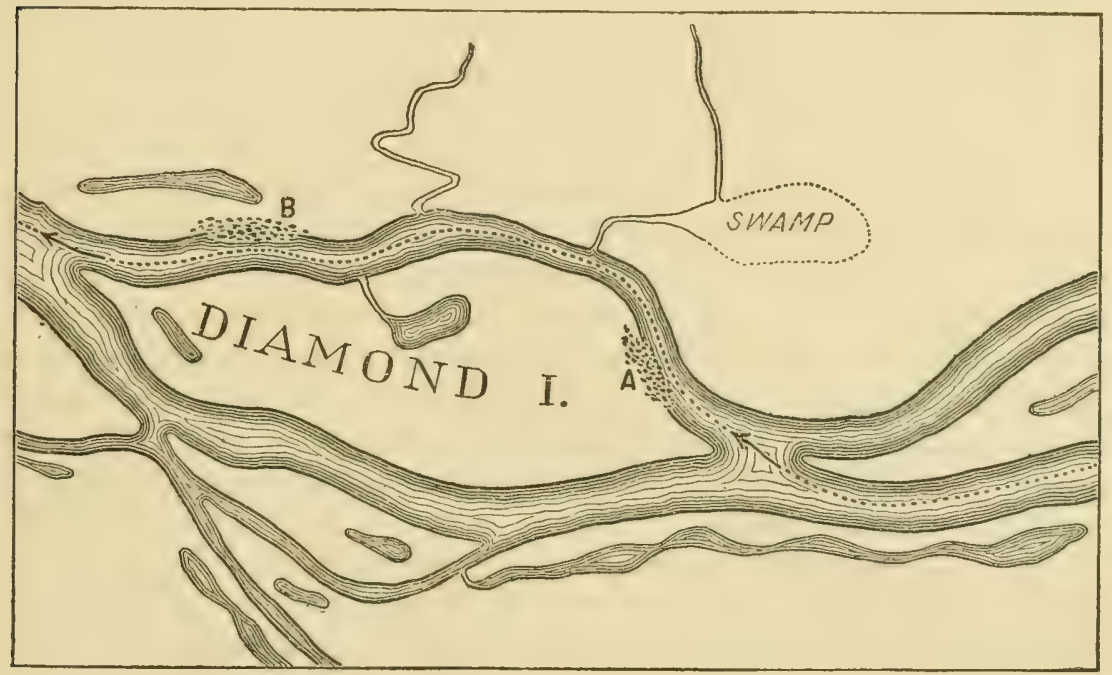

FIG. 1.

process of mud and sand. The mussels evidently could not keep pace with the settlings, as the deposit was rapidly forming, and were suffocated. The shells appear to be of the same species found in the river at those places, and are very fragile and limy white in color.

\section{METHODS OF THE ILLINOIS MUSSEL FISHERY.}

The mussel fishermen of the Illinois are, as a rule, practical rivermen who are familiar with the conditions of the river, the general habits of the fishes and mussels, and the methods of taking them, although considerable misinformation is in evidence, as, for example, the structure of the mussel, methods of reproduction, the names of the shells, the character of pearls; etc. Mr. Freeland states that the men who were first attracted to the mussel fishery of this stream were largely an indolent lot, who expected to find an easy fortune 
in pearls, and in their haste to do so, generally discarded the shells as worthless, or at best only of secondary importance. During the summer of 1907 only two men were found who said that shells and not pearls were the chief object of their work. When the mussel industry reached a firm commercial basis, however, this type of men practically vanished, and was replaced by the regular fishermen, farmers who work at mussel fishing during dull seasons on the farm, the professional mussel fishermen, and by others who were attracted to the river for pleasure and profit during a summer's outing. The mussel fishermen, when at a distance from home, often lire in tents or in rudely constructed houses situated at farorable places along the shore, and at times in substantial house-boats, which afford them shelter as well as an economical moans of moving their outfit from place to place as the season changes or their inclination prompts.

Almost all of the shellers have gasoline boats with which to carry on their work. There are two types of boats in use-the launch, of which there are a variety of designs, and the john boat; the latter is very popular, as it is comparatively cheap, easily made, affords plenty of room, and is perhaps better adapted for handling the necessary appliances. It has a broad flat bottom, square ends, long rakes, especially forward, and is from 14 to 18 feet long. The gasoline engines are from 2 to 20 horsepower. The advantages of a power boat over the rowboat are very apparent, namely, the greater distance possible to travel in a day, the readiness with which the camps can be moved from one locality to another, and the greater quantity of shells taken.

Crow-foot bar. - The ordinary mussel bar or brail with crow-foot hooks, common on most of the commercial rivers, is the principal apparatus used on the lower two-thirds of the Illinois. The bar is usually of iron, from 12 to 16 feet in length, and from threefourths to 1 inch in diameter. The strings carrying the hooks aro placed 4 inches apart. There are two types of mules, or underwater sails, as they are sometimes called, the common solid frame type and the roll mule. The latter is generally used on this river, and has some adrantages over the other, in that it can be rolled up and put out of the way when not needed, or used as a tent for protection against unfarorable weather, and it is claimed that it is botter adapted to change the angle of the boat when desiring to cross the mussel bed diagonally or to avoid a known hang-up. On some parts of the river scissor forlss or tongs are employed with fair success during part of the year, usually in low water. At those placos where it is impossible to use any appliance on account of snag.s and other obstructions, and where the water is not too deep, the shells are often taken by wading or diving, but owing to the necessary exposure this method is not very popular with the mussel fishermen. 
Dip net.--Since the time that the mussel fishery began on this rivor, it was known that Peoria Lake contained large beds of good commercial shells, but until 1911 no very successful method of taking them had been devised, scissor forks, oyster tongs, rakes, and the ordinary mussel bar with crow-foot hooks proving unsatisfactory. The dip net was introduced during the spring of that year and is now used there almost exclusively, as it is simple in construction, inexpensire, and especially suited to soft mud bottoms free from logs and hang-ups, and where there is but little or no current. Like the mussel bar, it gathers nearly everything in its path on the rirer bottom and even some little distance below. Besides the live and dead shells, and always plenty of mud, there are found at times in the net as the result of a haul some one or more of the following articles: Bottles, cinders, lanterns, old shoes and rubbers, folding anchors, spectacles, shotguns, picces of musical instruments, shovels, watches and rings, jugs of gasoline, monkey wrenches, waterworks keys, tin cans, corncobs, snags, etc.

It is not known who invented this valuable apparatus, but probably the idea developed from the fish dip net, which it resembles, by gradually changing its form to the substantial tool now employed. There appear to be no two dip nets alike, as the blacksmiths make them according to orders and the material at hand. However, the various designs and patterns are very similar, the main difference being in size. The method of operation is the same for all of them. In a general way the dip net consists of a heavy, flattish iron hoop of one piece, bent somewhat triangular in form, with two of its sides curred outward and fastened firmly with bolts to a pole or handle 16 to 20 feet long. The third side or bottom is straight and from 18 to 36 inches in length, and is usually provided with coarse teeth along its edge, which is bent downward. A net of 2-inch mesh, made of small chain or no. 96 trot line with a capacity of a bushel or more, is fastened to the hoop by means of chain links and trails behind it. A short rope or bridle attached to the two curved sides of the hoop leads to a single rope securel to the bow of the boat. When the water is rather deep, the boats are fitted with a boom pole extending forward from the bow, and the rope from the bridle is fastened to its end, thus giving greater length of rope and convenience of manipulation. Driven by a gasoline engine of from 4 to 20 horsepower, according to the size and weight of the dip net, the boat draws the apparatus through the water along the bottom. The greater the power, of course, the better the results. The operator stands in the stern of the boat and steers with his foot or leg, and at the same time puts the net into the water, usually at his right side and bears down heavily on the handle. The teeth on the lower edge of the hoop dig up the mussels which roll into the net. Unless the appliance be 
placed at the stern and in the direct line of travel, there is a retardation on one side only, and the boat consequently makes a large circle orer the mussel beds. When the tool is raised after making a haul, the mud and small shells are washed out by dipping the net in number of times into the river; the contents are then dumped into the bottom of the boat, to be sorted out, the trash and dead shells being thrown orerboard. The partner usually attends to this matter as well as

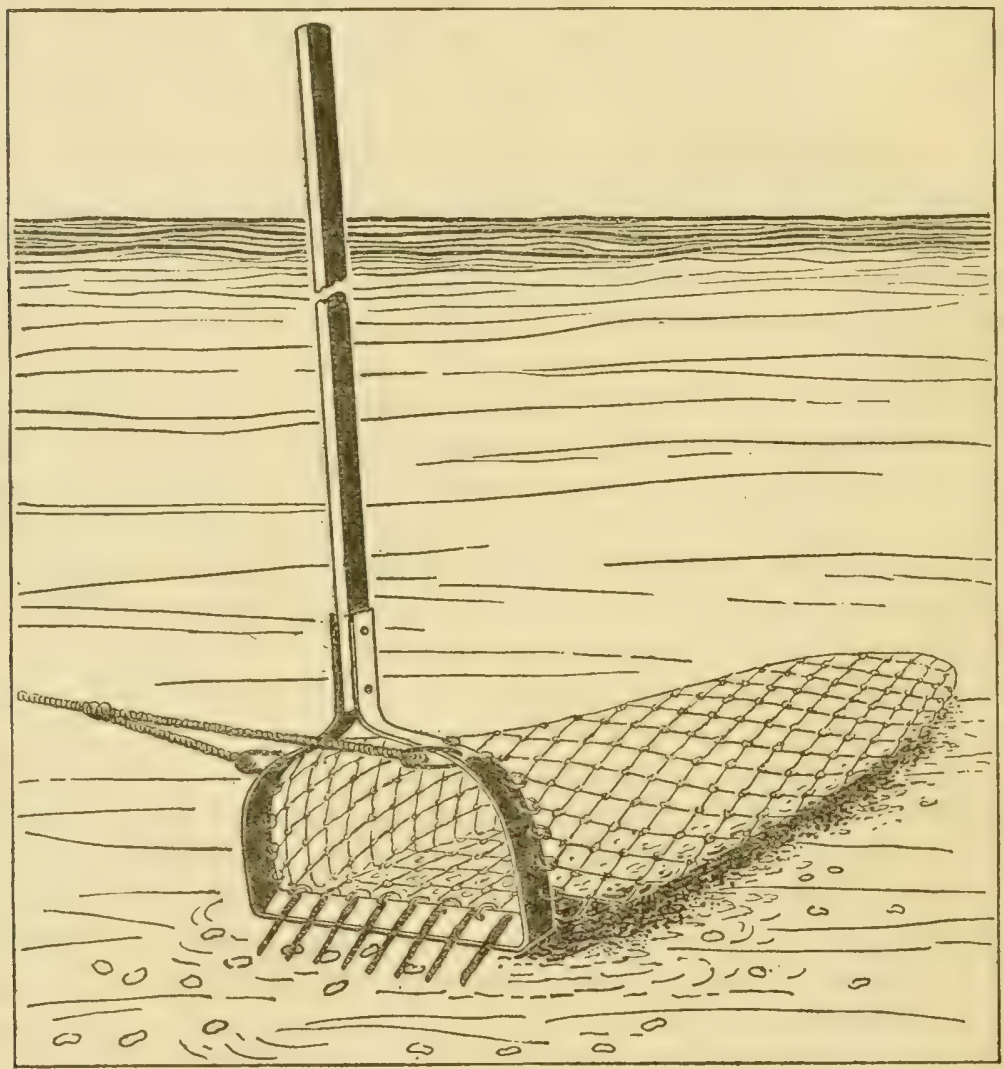

FIG. 2

looking after the engine. By this method of mussel fishing, two men or a man and a boy can easily dig in a good locality 1,500 to 1,800 pounds of shells in half a day.

\section{LEGISLATION.}

The legislature of Illinois has recently enacted a law looking toward the protection of mussels and the mussel fishery of the State. A closed season has been established for the navigable waters, extending from October 1 to April 1, inclusive. The boats are to be equipped with not more than two bars, which shall not exceed 16 feet in length, 
the hooks thereon to be at least 4 inches apart. Nonresidents must have a license costing $\$ 50$ for each boat.

In view of the threatened depletion of the mussel beds on the Illinois, it has been suggested by mussel fishermen and others interested in the industry that there should be a closed season on all the musselbearing rivers or parts thereof, extending over a period of three to five years; the rivers or the parts to be so arranged in series that some (sufficient to maintain the button industry) would be left open during the ordinary shelling season. It may be that this view would prove satisfactory, provided there was a uniformity of laws in the various States, or that the mussel fishing was under Federal control.

\section{THE PEARLS OF THE ILLINOIS.}

Very little pearling was done on the Illinois previous to 1892 , although some years before this date occasional pearl hunters made frequent trips and extended investigations from time to time over the greater part of the river. During the earlier period pearls alone were the object of the search, there being no particular demand for the shells, and, besides, the pearler of that day had neither time nor inclination to save them; they were left after examination, usually in small piles along the shore as a waste product. If a locality in which he was working did not show immediate results he would move farther along, always hoping and expecting to find a mussel bed which would produce a pearl of considerable value, thus amply reparing lim for his time and outfit. The pearl hunters are indeed the pioneers of the mussel industry, and in their extensive search for the elusive gems they have usually found not only the best mussel streams of the country but the best beds and the most productive portions of the rivers as well.

At the present time it might be said that the pearls and slugs are of secondary consideration and when found are regarded by the mussel fishermen as so much clear profit. The sale of slugs is generally sufficient to meet the actual running expenses of the camp and a pearl is considered as so much extra.

Beardstown, Ill., is a center for pearl buyers, and during the shelling season buyers are there from Paris, New York, and other places, besides the local dealers. One man claimed to have bought $\$ 20,000$ worth of pearls and slugs along this river in 20 days. $^{a}$

No particular work was done during the present survey toward the study of the origin of pearls; however, a number of distomids and cyst-forming parasites were observed in the meats of the mussels. The Illinois is a good river on which to carry on scientific pearl investigations, as it is rich in pearl mussels and affords many retired places

$a$ The writer is indebted to Messrs. J. H. Carner and Otto H. Fischer, of Beardstown, who furnished much information concerning the pearls and slug 3 of Illinois. 
and farorable mussel beds especially suited to pearl study. Among the most interesting localities for observing pearl formation and development may be mentioned Peoria Lake, Havana, Batlı, Beardstown, Meredosia, Pearl, and Hardin, at which places, as well as at many others, excellent pearls liave been found, and no doubt there are many more there yet to be taken.

FINDING THE PEARLS.

The cooking-out process of the mussels is an interesting and important part of the work in the camps along the Illinois. The mussels are steamed for 15 or 20 minutes in a crudely constructed vat, until the shells have opened and the meats may be readily taken out. Shells and meats are then transferred from the cooker to tho sorting table, and the parts there separated, tho meats being jut aside temporarily and the shells thrown into a near-by bin. The meats are then carefully examined one by one-a rery todious process, but well worth the trouble.

The slugs and other minor nacreous pieces when found are dropped into a glass of water on the sorting tablo and are afterwards cleaned, usually with soap or soap powder. A pearl, howoror, being much more valuable, recoives an entirely different treatment in that it is "tempered" by being placed in the mouth for a while, then wraplecd loosely in cotton, and put in a small tin box or other recoptacle for safe-lieeping. The pearlers and pearl buyers believe that this method of treating the gems prevents cracking.

"Does the boiling or cooking-out process of mussels injure the contained pearl?" is a question that is of ten asked and ono that has led to considerable discussion. From personal observations and from the statements of mussel fishermen and pearl buyers it appears that moderate cooking or steaming of the mussols does not injure the pearls at all, provided they do not fall out of the shells or become disengaged from the meats and thus reach the bottom of the cooker and got scorched. Some mussel fishermon who have had practical oxperience along this line of work maintain that moderate cooking is beneficial rathor than detrimental, inasmuch as the process "cures" the organic matter of the pearl and renders it less liable to crack or otherwise to deteriorate. However that may be, it is very evident that by far the greater percentage of the pearls and slugs are found after the mussels have been cooked, the exception being for these shells which show distortion or some other poculiarity, when they are generally opened with a knife as soon as found. 


\section{CLASSIFICATION OF PEARIS.}

There appears to be no definite standard or classification for the almost unlimited variety of shapes and kinds of poarls and slugs, and even on the different parts of the same river the irregular nacreous formations are variously named by the pearler's and buyers, according as fancy directs or to the resemblance to some familiar object. $\Lambda$ t times the classification is made under three heads-pearls, baroques, and slugs, each class with a number of subdivisions depending for names upon the particular shape of the pieces; and at other timas there are but two heads-pearls and slugs. The following are the names and classifications generally used on the Illinois and includes most of the different kinds of pearls found there:

\section{Pearls:}

Ball or round pearls are those which are spherical in shape.

Pear pearls, including the drop, the egg, and the top pearls, depend for the name upon the resemblance in shape to a pear, egg, or top.

Button pearls, shaped somewhat like a button, biscuit, or saucer, have a more or less arched top and a flattish bottom.

Capsule pearls have a shape bearing a resemblance to a cylindrical medicine capsule such as is used for quinine.

Banded pearls are oblong in shape, with ridges and grooves around the middle portion which have the appearance of bands.

Cone pearls have a flattish bottom with the sides of the pearl running to an appex like a cone.

Baroque pearls include a great variety of forms which are irregular in shape without any particular pattern.

Rosebud pearls are of various shapes, usually having a flattish base; the upper portion is more or less covered with small protuberances, giving it at times a somervhat warty appearance.

Turtle-back pearls have a rather flat base and a low arched top, resembling somewhat the back of a turtle.

Besides these forms, there may be mentioned the dumb-bell, the cylinder, the Slugs: twin pearls, etc., which are occasionally found.

Spikes or points, including wings, are usually placed under the head of slugs, although if they are of sufficient size they are sold as single pieces. Spikes or points are usually long, flat, and often pointed pearls found near the lateral hinge of the shell, while wings are broad, flattish pearls bearing a resemblance to the wings of a bird.

Nuggets and chunks are often classed together, with the difference that the chunks are much larger. They are irregular pearly formations resembling somewhat a gold nugget in shape.

Slugs include irregular pearls having no particular name and without much value and called "mixed;"- also small or seed pearls, "chicken feed," etc. Slugs of this class are usually sold by troy weight, and are worth, according to quality, from $\$ 3$ to $\$ 3.50$ per ounce.

The ball, the pear, and the button pearls are the most valuable, although the capsule and some other forms often command a high price if they be symmetrical in shape and of fair size and good luster. 


\section{POSITION OF PEARLS IN MUUSSEL SHELL.}

Pearls are usually found in the mantle near the tip or posterior end of the mussel, while slugs and other pieces may be found in various parts of the body, along the lateral hinge, at the cardinal teeth, in the adductor muscles, and in the shell itself, etc.

Sometimes a pearl becomes attached to the shell, after which it may be corered over by deposits or layers of nacre and is then said to be embedded. These pearls can be recorered by sawing the shell around the observed protuberance or by carefully removing the inclosing layers. Many shells hare what are commonly called "blisters," which are successire pearly deposits orer mud, muddy watcr, organic matter, or some foreign substance finding its way into the mussel. It illustrates a method the animal uses to remedy a disturbance within. Blisters, as found in the Unios, have no commercial value. There are found occasionally in the meats of the mussels cartilaginous formations which are denominated by the fishermen as "soft pearls undergoing the process of formation into true pearls." It is claimed that soft pearls are caused by a grain of sand or other foreign body.

PEELING A PEARL.

As pearls are composed of thin concentric layers of nacre and conchiolin or animal substance, each separate and distinct, peeling or remoring some of the outer layers of the various forms of pearls to improve the gems is often done successfully by one versed in this line of work. Pearls haring a dark spot, stain, or chalky appearance over the entire surface, or even a part of it, are greatly diminished in value. When such is the ease it is often worth while to try the experiment of peeling, as the result will probably be satisfactory and a good pearl obtained from within. However, it may be stated that fairly good pearls have been damaged rather than improved by peeling, as the inner layers were in a worse condition than those at the original surface. A fine, pink, high-button pearl of 40 grains and worth $\$ 800$ was seen this summer. The pearl had a small spot on the side and might have been benefited by peeling, but the owner, considering its present value and the uncertainty of the result of peeling, would not take the risk.

\section{CRIPPLED SHELLS.}

Occasionally the various mussel beds of the Illinois produce a few cxamples of distorted or injured mussels, commonly called "crippled shells." They are regarded by the pearler as excellent finds and are generally opened at once without waiting for the cooking-out process, with the hope that a piece of some value may be present. 
Those shells which have received an external injury, however, and are distorted in consequence, seldom contain anything of value; but it does appear unquestionable that other distorted shells owe their peculiar condition to the presence of a pearl; the abnormal shape is the direct result of an accommodation to the disturbing nacreous growth within, which as it slowly derelops maintains its position relative to the margin of the mantle and valves. Certain shells which have come to the writer's attention contained valuable pearls as well as showing clearly the abnormal condition. As viewed from the outside, such shells have a slight and gradually broadening ridge running diagonally down from near the beak or umbone to the tip or the posterior end on one valve and a corresponding valley or depression down the other. Within the shell the opposite condition of the ridge and valley is true. From this circumstance it is possible to estimate with some degree of accuracy the age of the pearl by the lines of growth on the external surface of the shell, noting where the disturbance begins and ends. In studying these distorted shells the peculiar fact is brought out that the pearl is always on that side of the shell whose valve shows, viewed extemally, the valley or depression. In a large percentage of these distorted shells the pearls have been found on the left valve. The pearl, near the margin of the mantle, causes the abnormal action of the latter, which produces the slight inward curve of the nacreous deposit, so that it might be said that the pearl lies on or near a ridge. For the opposite valve the mantle condition is reversed, resulting in the outward deflection of the nacre, or the valley.

Some of these apparently valuable crippled mussels contain no pearl whatever, although the evidence is plainly written, both within and without, in the texture of the shell. When this condition is observed, the pearls are said to have been lost or "shed." If the pearl were lost some years before the mussel was taken, the shell often recovers in part its natural shape from that time on, as shown by the lines of growth and the posterior edge or lip, and it is hardly worth the time and trouble to try to find a pearl within.

Accompanying plates show some examples of distorted or otherwise injured mussels and will assist in understanding this interesting subject.

\section{QUALITY AND VALUE OF ILLINOIS PEARLS.}

The quality of the Illinois River pearls and slugs, though very good, does not quite equal that of the pearls and slugs of the Wabash and some other tributaries of the Mississippi. Nearly all of the different species of mussels have produced pearls and slugs, but the washboard (Quadrula heros) is the principal pearl-bearing shell of the Illinois, and the blue-point and three-ridge (Q. undulata and plicata) are among the 
best slug producers, although the warty-backs $(Q$. pustulosa) occasionally have good specimens of the latter. Some of the paper shells and floaters were observed to have a number of attached pearls, appearing for the most part at the tips or posterior ends of the shells. These pearls, as a rule, are of no value except from the standpoint of the experimenter.

The average yield of slugs for the entire river will not exceed, perhaps, onc-half ounce per ton of shells, while the percentage of good pearls is very small indeed. Many valuable gems, however, have been found in this river during its shelling history. It is difficult to determine the value of the Illinois Rirer pearls and slugs for 1912 or for prerious fears, as there are many buyers traveling along the stream during the shelling season who make private purchases of them, paying for the slugs from $\$ 3$ to $\$ 3.50$ per troy ounce. Pearls ranging in value from $\$ 5$ to $\$ 25$ and upward were found in 1912 at nearly all the principal mussel beds from Hennepin to below Hardin. Among the best finds may be mentioned the following: Three fine pearls were found in Peoria Lake and sold for $\$ 1,100$ each, and one exceptionally fine pear pearl of beautiful luster, weighing 64 grains, sold for \$2,500. One at Pearl, Ill., sold for \$2,700, and one found at Hardin brought $\$ 750$. The news of such good finds spreads rapidly throughout the locality and is a great stimulus to the pearl and shell industry. The pearlers become expert in their line of business and can usually tell at a glance from what general class of shells the pearls and slugs are taken. For example, it is well known to them that the lower river beds produce "washboard stuff," which is very white, although some of the pieces may be stained similar to the spots in the shell, and the upper river stretches yield a large quantity of "bluepoint stuff," often having a tinge of pinkish color. 
Table 9--Distribution of Mussels at the Principal Stations Along the ILLINOIS RIVER.

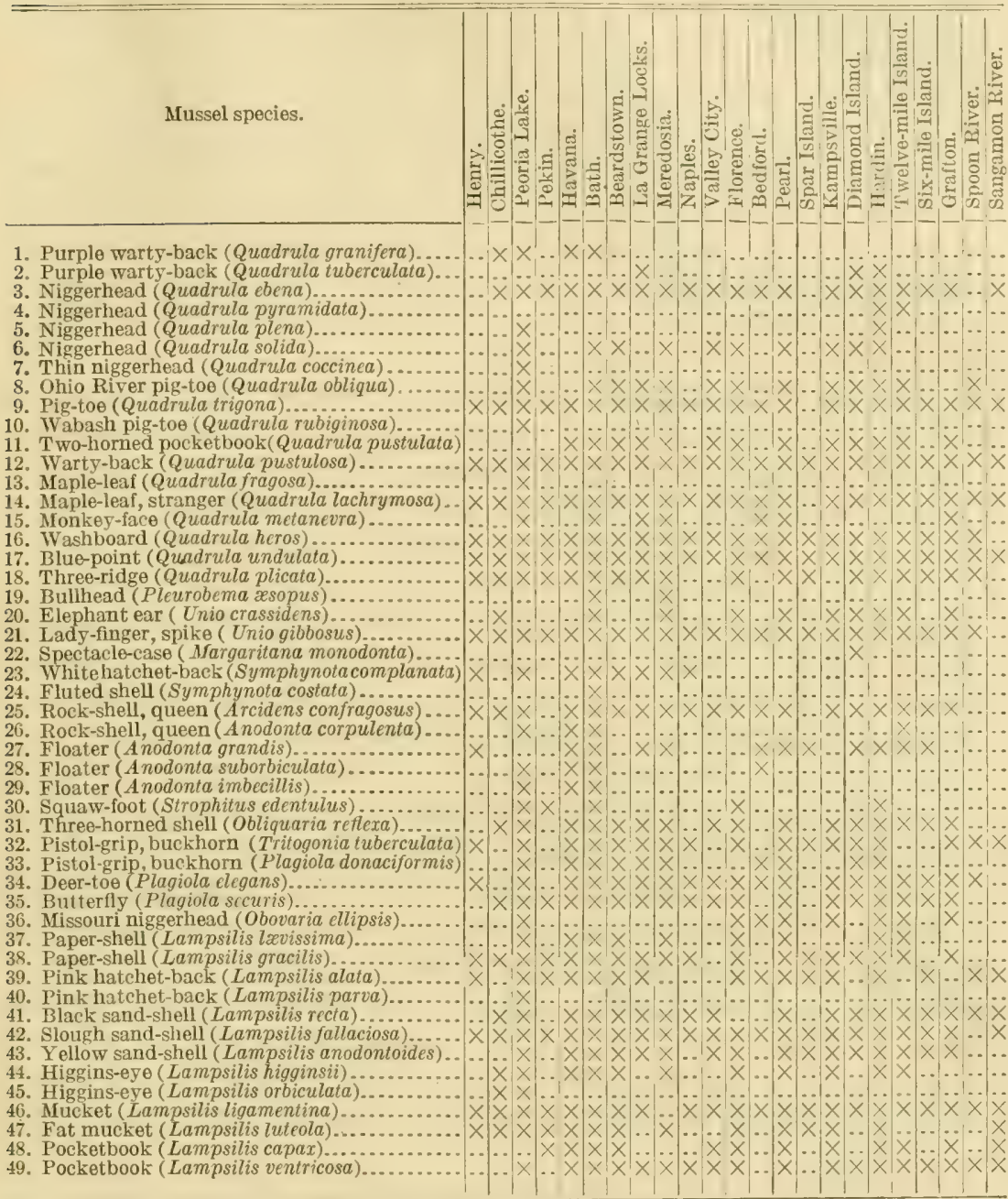

MUSSEL SPECIES.

There have been recorded about 63 species of Unionidre from the Illinois River and its principal tributaries. ${ }^{a}$ During the present investigation, however, the following 49 species were found in the main stream. About 20 of these are suitable for manufacturing purposes, although only 6 or 7 occur in sufficient quantities to be of practical worth.

a Baker, Frank Collins: A catalogue of the Mollusca of Illinois. Bulletin of the Illinois State Laboratory of Natural History, vol. vII, art. VI, September, 1906. 
1. Purple Warty-Back, Quadrula granifera (Lea).-This is a rather rare shell in the Illinois, although a few examples were found in the upper half of the shell-producing portion of the river at Chillicothe, Peoria, Havana, and Bath. It is an inflated shell, heary anteriorly, and reaches a good size, but on account of its dull purple nacre it is not now used for the manufacture of buttons. After the cooking-out process, this shell is discarded by the mussel fishermen as worthless. The purple warty-backs, paper-shells, lady-fingers, and other culls are gathered along with the commercial species, and although they are known to be of no particular value, they are saved for the meats for fish bait, and also because they occasionally produce good pearls.

2. Putrle Warty-Back, Quadrula tuberculata (Rafinesque).Rare; some examples of this mussel were found in the lower stretches of the river where the water is swifter, as below the Government locks at La Grange, at Diamond Island, and at Hardin. There appears to be a more or less gradual change from the inflated granifera of the upper stretches, where there is but little current and the bottom is composed largely of soft mud, to the much flatter tuberculata of the lower river where the bottom is harder and the current is stronger. This shell, like the granifera, has a dull purple nacre, and at the present time has no commercial value.

3. Niggerhead, Quadrula ebena (Lea).-On account of its good size, firm texture, and fine pearly luster this is the most valuable button shell of the United States. Near the tips it produces a few iridescent buttons. Although widely distributed throughout the entire river, this species is so rare in the upper stretches that often only one or two examples are found in a ton of shells. In the lower third of the river the conditions are better; the number may run as high as 2 or 3 per cent. It has been stated that eight or nine years ago the ebena and ligamentina (mucket) were fairly abundant in many beds of the Illinois, though the indications are that the former was never very plentiful.

Some mussel fishermen are of the opinion that the annual deposit of sediment, covering up the beds, is one reason for their diminution. Mr. J. F. Mayes, of Meredosia, Ill., has tried an experiment along this line, and states that if a washboard (heros), niggerhead (ebena), and a mucket (ligamentina) are put into a bucket and water and sand are added only the washboard will reach the surface; the others will be suffocated. This may explain the situation for some beds where the silting occurs rapidly at a time when the animals are more or less dormant, but does not appear satisfactory for the entire river.

Some examples of ebena taken at Peoria and Florence have the umbones wide apart, and are similar to Call's figures of this species, 
as illustrated in his paper on Mollusca, in the Indiana Geological Report, for 1899 .

This species was found gravid, early embryo, all four gills, July 12.

4. Quadrula pyramidata (Lea).-Rare; a few samples were found in the last stretch of the river at Hardin and at Twelvemile Island. This shell is very heavy anteriorly and thin at the tips. Some examples have pink nacre. This and the two species following are usually classed with and generally called "pig-toes" by the mussel fishermen.

5. Quadrula plena (Lea).-Rare; an example or two were found at Peoria and Hardin.

6. Quadrula solida (Lea).-A comparatively rare species, although found in several mussel beds from Peoria to Hardin, more particularly at Peoria, Beardstown, Meredosia, and Valley City. The nacre varies from white to salmon. This shell furnishes good button material.

7. Thin Niggerhead, Quadrula coccinea (Conrad).--This is a very rare species in the Illinois. Some examples were found in Peoria Lake.

8. Оhio River Pig-toe, Quadrula obliqua (Lamarck).--This shell, while not a common one in the Illinois, is found generally distributed throughout the river. It furnishes good button material, but is hardly equal in size or quality to the species in the Ohio River beds.

9. Pig-toe, Quadrula undata ${ }^{a}$ (Barnes).-Although this species in the Illinois is the most abundant of the "pig-toe" group, it forms but a small percentage of the mussel output. Some beds, depending upon the parts worked, gave the following percentages: Chillicothe, 7 ; Pekin, 3; Florence, 9; and Hardin, 2.

This is a good button shell, but has considerable waste on account of the heary umbones. At Peoria small undatas just large enough to make one blank were taken and sold by some of the mussel fishermen. As an excuse for these small shells in their piles they said, "The pigtoes are running smaller now."

Some examples had orange flesh. Found gravid in all four gills June 20.

10. Wabash Pig-toe, Quadrula rubiginosa (Lea.).-This is a rare species in the Illinois. The only examples found were taken from Peoria Lake.

11. Two-нorned Pocketвooк, Quadrula pustulata (Lea).Although this mussel is generally distributed throughout the river, it is found in very small numbers. It is usually classed with the pustulosa, or warty-backs, but is hardly as good material for manufacturing purposes.

a According to Mr. Bryant Walker, Nautilus, vol. Xxrv, p. 6, the name undata has precedence over the one (trigona, Lea) commonly used. 
12. WARTY-BACK, Quadrula pustulosa (Lea).-The pustulosa, or warty-back, is a rery common shell in the Illinois, certain very productive beds yielding a large per cent of the output. This mussel, though thin at the tips and in old specimens heavy at the beaks, is of good size, quality, and luster and often classed next to the niggerhead for manufacturing purposes. There are a number of variable forms of this species among our examples, one of which (no. F 6245), found at Henry, Ill., June 19, was referred to Mr. Bryant Walker, who states that it "is a young and very much inflated dorfeuilleamus, which Simpson calls a synonym of pustulosa. I think it quite likely that some day it may be given varietal rank." This mussel of ten contains a number of slugs; one of our examples had nearly 50 small nacreous pieces at the dorsal part of the body. Found gravid July 5 .

13. Maple-Leaf, Quadrula fragosa (Conrad).-Rare; an example was found in Peoria Lake, but it does not agree exactly with fragosa as we found it in the Cumberland River, near Clarksville, Tenn.

14. MAPLE-Lenf, Quadrula lachrymosa (Lea).-Lachrymosa, while not common, occurs in small numbers in practically all the mussel beds of the river. Some examples of this shell found with projecting tuberculcs, appear to be the form described as asperrima, now a synonym. This shell has good luster and size in the Illinois and is usually classed as first-grade material. One example found in the Spoon River measured $4 \frac{1}{2}$ inches in length.

15. Monkex-Face, Quadrula metanevra (Rafinesque).-A rare species in the Illinois, but few specimens being found at the stations given in the general table on page 37 .

The green triangular markings so prominent in well-defined species are faint in our specimens. Some examples vary considerably in shape and general appearance. One is heavily pustulose anteriorly, many of the pustules being elongate along the lines of growth, and is strongly suggestive of $Q$. pustulosa. Another of our examples has the markedly pinched posterior dorsal portion generally pronounced in this species in the lower Wabash. All of our shells are noticeably inflated.

16. WaSHBOARD, Quadrula heros (Say).-Heros is the best button shell of the Illinois and produces the most blanks per ton, but in some localities is porous and does not do well for an engraved button. The three-ridge type makes a better finished button. In the upper stretches of the river the complete washboard shell averages about 1 pound in weight and is frequently spotted; but from below Beardstown to Twelvemile Island it is much smaller, flatter, freer from spots and stains, and of good luster. At Hardin this shell is no larger than the undulata or bluepoint of Peoria Lake, even old examples called "bald-pates" found in the channel are small. 
In some localities, as at Quiver Lake, above Havana, the old heros are dead; not a single living example was taken, excepting the young; indicating that whatever the cause of the mortality had been, more favorable conditions exist at present.

Small shells 2 or 3 inches long are taken by the mussel fishermen; and while they make a few good blanks, to take them is rery wasteful, as they should be thrown back into the river and allowed to mature.

In our collection there are three examples of this shell, which show very clearly the abnormal ridge and valley caused by the growth of pearls within. Two of the shells were found near Bath, Ill., and the other at Peoria.

Plate II represents a heros or washboard, measuring $4 \frac{5}{8}$ by $6 \frac{1}{2}$ inches. The nacre is remarkably clear. From the entire shell, 5 dozen 24-line blanks were cut at the button factory of Mr. J. H. Carner, Beardstown, Ill.

17. Blue-Point, Quadrula undulata (Barnes).-The undulata is a very abundant species and is regarded by the button men as a very desirable shell. It is rather flattish, particularly at Chillicothe, though lower down the river it is somewhat more inflated. It is rather thin and light in weight but of good size and luster.

The shell is commonly called the blue-point, but in some camps the name of "purple-tip" is applied to it on account of the slight purple tinge at the posterior end.

$A$ few examples almost free from ridges were found in Peoria Lake and at Florence, Ill. Prof. Richardson, of the State biological station at Havana, had two similar specimens taken from the river at that place.

This mussel was found spawning July 12.

18. Three-RIDge, Quadrula plicata (Say).-The three-ridge is much less abundant and not so valuable a shell as the blue-point. Being usually more inflated, heavier at the beaks, and with larger ridges, it leaves more waste after the blanks are cut.

At Meredosia, it is claimed that the plicata has a tendency to crumble when cut. Found gravid July 8 and 15.

19. Bullhead, Pleurobema resopus (Green).--Rare; examples were found only at Bath and Meredosia. It is brittle and not a good button shell; moreover, being so uncommon in the Illinois, it is disregarded altogether.

20. Elephant-Ear, Unio crassidens (Lea).--Rare; although found in most of the beds, the pereentage is so small that it is practically a negligible quantity. The nacre varies from pink to white. This shell is used for making novelties.

21. Lady-Finger, Spike, Unio gibbosus (Barnes).-The lady-finger is not now a commercial shell unless it be white, which is seldom the 
case. It is found in large quantities along the river, some beds, which the clammers avoid as much as possible, having a very large percentage. Above the upper bridge at Peoria there are two small beds of this species; one bed consists mostly of white nacred shells, while in the other the nacre is the ordinary dull purple color. At Meredosia a driveway leading from the river to the bank above is covered with about 60 tons of these shells. They had been purchased at a low price in the hope that there would be a demand for them. Button cutters claim that even the white gibbosus do not make good blanks on account of the shell being brittle.

In the Cumberland River, crassidens is much more abundant than gibbosus, which is the poposite condition in the Illinois.

22. Spectacle-Case, Margaritana monodonta (Say).-Rare; only one example was found during the entire trip, at Diamond Island, above Hardin, although there were some specimens from this river at the biological laboratory at Havana, Ill. The shell is too thin and brittle to be of any commercial importance. Not so large as the Cumberland River species.

23. White hieel-splitter, Symphynota complanata (Barnes).-When of sufficient thickness, this shell is used for buttons. It is fairly common in the Illinois, and from its flat shape and outline is often called the "clephant-ear" by the mussel fishermen. It is found in sloughs and in mud bottoms.

24. Fluted-SIIEll, Symphynota costata (Rafinesque).-Rare; only one example found, at Bath.

25. Rock-shell, Bastard, Queen, Arcidens confragosus (Say).Found in small quantities on almost all of the mussel beds. It is not regarded as particularly good button material. This shell is sometimes called the black pocketbook, rock pocketbook, and bastard. An extra large and inflated example was found at IIavana, June 28.

In young examples of confragosus the interior surface of the shell is indented or pitted to conform with the more pronounced pustules on the outside. This condition at the end of probably two years disappears, the shell becoming covered with subsequent layers of nacre.

26. Anodonta corpulenta (Cooper).-Four Anodontas, the corpulenta, grandis, suborbiculata, and imbecillis, were found during the present survey. They are thin, paperlike shells and have no commercial or economic value, excepting perhaps as they are used occasionally by the mussel fishermen for fish bait or hog feed. The corpulenta is found in sloughs, and on soft mud bottoms.

27. Floster, Anodonta grandis (Say).-Distributed as the preceding species. Shells which have recently been killed rise to the surface of the water on account of the gases of decomposition and 
are seen floating along with the current; hence the common name of "floater." Grandis and corpulenta are often affected with parasites, particularly at the posterior end. Our examples were all of only moderate size as compared with shells seen in retired places along the Cumberland.

28. Anodonta suborbiculata (Say).--Suborbiculata is widely distributed and is generally found on mud bottoms and in slack water.

29. Anodonta imbecillis (Say).-This small, delicate shell is very abundantly distributed, especially in the more retired places of quiet waters. Found gravid June 27 and July 2.

30. Squaw-Foot, Strophitus edentulus (Say).-Found rather scattering throughout the various stretches and mussel beds of the river. The nacre is usually of a yellowish color. This shell has no particular commercial value, although some examples are found which are of sufficient thickness and size for manufacturing purposes.

31. Three-horned Shell, Obliquaria reflexa (Rafinesque).-This mussel is widely distributed and is usually of small size. There are two or three forms of reflexa found in the Illinois. In the upper stretches of the river it is of the ordinary shape and size found in other streams, and although it can be used for manufacturing purposes it is not a particularly valuable shell to propagate. In the Peoria Lake region, however, where the current is slow and the bottom is composed of soft mud, the shell is often very heavy and rounded anteriorly, while posteriorly it is thin and much elongated, which no doubt is the result of accommodation to natural conditions. In the lower stretches the shell, though heavy and inflated, is considerably smaller than those in the upper portions of the river. A number of our examples have five tubercules on each valve. Found gravid June 27 and July 3.

32. Buckhorn, Pistol-grip, Tritogonia tuberculata (Barnes).Although this interesting species is comparatively rare in the Illinois, it is widely distributed. The name of pistol-grip is applied to it in some localities, owing to the fact that it fits the hand like a pistol. The characteristic ridge of this shell gives it somewhat the appearance of the abnormal ridge found occasionally on the heros or washboard as the result of pearl growth. While this shell has a ridge on each valve, the abnormal washboard has but one valve ridged, the other having a corresponding valley.

The buckhorn furnishes good material for the manufacture of buttons and novelties.

33. Liтtle Poскетвоoк, Plagiola donaciformis (Lea).-This small mussel, although of no commercial value, is very common in the Illinois. There are two types of this species found in many beds, differing in shape to a certain extent and particularly in color. On 
account of its resemblance to $L$. ventricosa it is often called the "little pocketbook." Found gravid June 27 and July 4.

34. Deer-toe, Plagiola elegans (Lea).-This beautiful species is found in small quantities throughout the entire river. It is hardly considered a commercial shell, but the larger and thicker cxamples are often seen in the mussel camps and piles along the shore. The length of the largest shell of this species found during the survey was $2 \frac{3}{4}$ inches $(70 \mathrm{~mm}$.). Some examples, particularly from those portions of the river having soft mud bottoms, are greatly elongated posteriorly, and others bear a strong resemblance to $P$. donaciformis.

There are two forms of elegans found in several of the mussel beds of the Illinois, particularly noticeable at Peoria. The common form is the more abundant and compares favorably with the species in the collection of the Unionidx at the Bureau of Fisheries and with those found in the Maumee and Wabash Rivers. The other form is proportionately more infiated, and has brownish epidermis, darker posteriorly, with dark capillary lines. The pseudocardinal teeth are heavy and curved; the laterals are broad and striate. The nacre is pink. The truncated shape gives it somewhat the appearance of Truncilla triquetra (Rafinesque). Some fine examples were found near the upper bridge, at Peoria, Ill., June 27.

35. Butterfly, Plagiola securis (Lea).-The butterfly, or securis, is not a common species in this river, although many of the beds could be made to yield productively by propagation. On account of its flatter shape and proportionally lighter weight, the male shell is more valuable for commercial purposes than the female.

36. Missour niggerhead, Obovaria ellipsis (Lea).-This species is comparatively rare in the Illinois Valley, but some examples were found from Peoria Lake to the mouth. This shell has a velvety epidermis and a good pearly nacre and furnishes good button material. The ellipsis appears to be closely related to higginsii.

37. Paper-Shell, Lampsitis tevissima (Lea).- This shell is fairly common in the river, and at the present time has no economic value. In nearly every example examined at Beardstown and a few other place, , this mussel was more or less diseased at or near the tips or posterior end, due to parasitic infection.

38. PAPer-SHell, Lampsitis gracitis (Barnes). -This mussel resombles the preceding species. The shell is thin and has no commercial value, though the meats or soft parts are used occasionally for fish bait. Found gravid June 27.

39. Pink Heer-splitter, Lampsitis alata (Say).-This species is fairly common and is found mostly on mud bottoms. It has no commercial value. One of our examples, taken at Hardin, is thick enough for manufacturing purposes and has a good white nacre. 
40. Lampsilis parva (Barnes).-A rare species; one example found in Peoria Lake. This is a small, delicate shell of no economic value.

41. Black SAND-Shell, Lampsitis recta (Lamarck).-The black sand-shell is a rather common one and reaches a very large size in this river. It is found in the lakelike places of the stream and in the swifter parts of the lower stretches. The nacre is generally pinkish or purple and, although the texture is good, the shells are discarded by the mussel fishermen and buyers, as there appears to be no particular demand at the present time for colored shells. The white-nacred ones, though much less abundant, are always saved. They are usually classed along with the yellow sand-shell, and are mad : use of in novelty factories. In the mussel camps this shell is often called "lady's slipper," on account of the appearance of the valves when opened out flat.

42. Slough SAND-Shell, Lampsitis fallaciosa (Smith).-Abundant; usually found standing on end burrowed in the mud of sloughs and bays or along the shore where there is but little current. When of sufficient size and thickness, they are classed with the yellow sandshell. In Peoria Lake the fallaciosa are beautifully rayed.

Some doubt has arisen as to whether this species is identical with anodontoides, but it appears on the Illinois to be a distinct species. Our examples are markedly different from anodontoides of the same region. The fallaciosa vary greatly in distinctness and abundance of rays, some being but faintly rayed, others with many broad pronounced green rays. One example, a fine large male, is so heavily rayed as to be almost green, and approaches more nearly than any of the others the general form of anodontoides, but could not well be confused with that species. A well-rayed female of moderate size is noteworthy for a marked reddish-orange cast of the epidermis, the shell beneath having a rosy tinge. Another constant difference in our examples is the cardinal tooth of the right valve, which is compressed and almost lamelliform in fallaciosa, while in anodontoides it is more triangular.

It is quite possible that the convergence of the two species in the southern and southwestern portions of the United States is due to the different features of bottom and general abundance of silt and slough-like conditions in the lower courses of rivers, which would cause all to assume the characters of the slough-dwelling form.

43. Yellow SAND-Shell, Lampsitis anodontoides (Lea).-This species is found sparingly throughout the upper river, but is fairly abundant in the Hardin district, where it is in sufficient quantity to be sorted out and sold separately at an advanced price. This shell is the most valuable of the fresh-water mussels, and as it is easily propagated, many of the beds where the conditions are favorable could be restored. It prefers deep water and clean sandy bottoms. 
Our examples have a rich yellow epidermis, and are appropriately called "banana shells" in some localities. This shell is valued at about $\$ 60$ per ton.

44. Higgins-EYe, Lampsitis higginsii (Lea).-Not common, though widely distributed, particularly orer the lower half of the river. The males sometimes bear a strong resemblance to Obovaria ellipsis. There are four females in our collection and they present marked differences and peculiarities: One is normal and requires no comment; another flattened, flaring posteriorly, and suggests permanent sterility; another example has that portion covering the brood pouch strongly inflated, the portion of the shell immediately behind it underdeveloped and a trifle sulcate, forming a slight emargination; the general form suggests overdevelopment. The remaining example somewhat resembles this, but is flatter.

45. Lampsitis orbiculata (Hildreth).-This species has good luster and thickness. There are two examples in our collection, one from Chillicothe and the other from Peoria. The nacre of one is rather pinkish. This species is difficult to separate from higginsii, but is generally more southern in distribution.

46. Mucket, Lampsitis ligamentina (Lamarck).-The mucket occurs in small numbers throughout the entire river but is more plentiful in Peoria Lake than elsewhere. This mussel is usually smaller and thimner than those of the Kankakee, Fox, and Wabash Rivers, but nevertheless is regarded as a first-class commercial shell and is a very desirable species for propagation. Our examples and those seen in the shell piles along the shore have a pearly white nacre, while in some rivers - as, for example, the Nississippi-there are found a fair percentage with a pinkish color. The mucket was found gravid, late embryo, July 9.

47. Fат Mucket, Lampsitis luteola (Lamarck).--The fat mucket is widely distributed, though like the preceding species it is more plentiful in Peoria Lake. The male shells are much more desirable for button purposes than the female, the latter, especially in the older specimens, being more inflated and more troublesome to cut. This shell is often called the black mucket and pug-nose mucket. Found gravid June 27.

48. Роскетвоок, Lampsitis capax (Green).-This is a rare species in the Illinois, and was found more frequently below locks and dams where the water was swifter. It is not a desirable shell to propagate.

49. Роскетвоок, Lampsilis ventricosa (Barnes).-While this species is not a common one, it is more plentiful than the preceding mussel, and, like it, was more abundant in the swifter parts of the river, as below locks and dams. Some beautiful young examples, having a very delicate pink nacre and fine epidermal markings, were 
taken, especially at Peoria and Meredosia; this is a remarkable condition for so muddy a river as the Illinois. This pocketbook, though inclined to be brittle, is usually good button material.

\section{SUMMARY AND CONCLUSIONS.}

The Illinois river is 273 miles in length, and, from a mussel fisherman's point of view, it is one of the most important tributaries of the upper Mississippi.

Sewage pollution, with perhaps one or two exceptions, does not appear to have decreased the abundance or quality of the shells within the last 180 miles of the river.

The dip net is used almost exclusively in the Peoria Lake district and a few other places where similar lakelike conditions exist.

The price per ton of the river run of commercial shells during 1912 was $\$ 12$ to $\$ 13$.

Some excellent pearls have been found, ranging in value from a few dollars to $\$ 2,700$. Slugs do not average more than one-half ounce per ton of shells.

The laws relating to mussel fishery have been generally observed.

There are 15 button or blank factories, with about 250 machines, along the river. The raw material is being better utilized than formerly.

The abundance of dead shells on many of the mussel beds may be due in part to the lack of erosion of the water and to the injurious effects of the crowfoot hooks.

The levees which have been heretofore and are now being constructed, particularly in the lower stretches of the river, reduce to a large extent the breeding grounds of the valuable species of fishes and incidentally affect the future supply of the mussels. During their early life mussels are parasites upon fishes for a period of from two to six weeks, and if the fish supply is greatly reduced it is readily seen that the mussel supply will also be materially reduced.

The washboard, or blue-point (Quadrula), group of mussels predominates in the Illinois. The slow current, mud bottoms, good average depth of water, and large fish resources all tend to make the river an ideal one for this group. The niggerheads (ebena), although apparently never very abundant, have become greatly reduced in numbers, from a cause not definitely determined. The old washboards (heros) in some places, as at Quiver Lake above Havana, have been killed, though the present conditions there appear to be more favorable.

The mucket (Lampsitis) group is found scattered in small quantities throughout the entire river, but more abundantly in Peoria Lake and the lower stretches. 
The Illinois has been the most productive stream per mile of any in the country. There are but few places within the limits of shell production that do not support mussel beds, though certain stretches, as between Peoria and Kampsville, show marks of depletion.

The immediate future of the Illinois is good, but unless suitable mussel propagation is introduced and carried on under proper management, the river will become depleted within a few years and a valuable source of revenue thus be lost to the State.

There are several good localities where the propagation of mussels could be carried on successfully, as at Peoria, Havana, Bath, Beardstown, Meredosia, Pearl, Kampsville, and Hardin. 


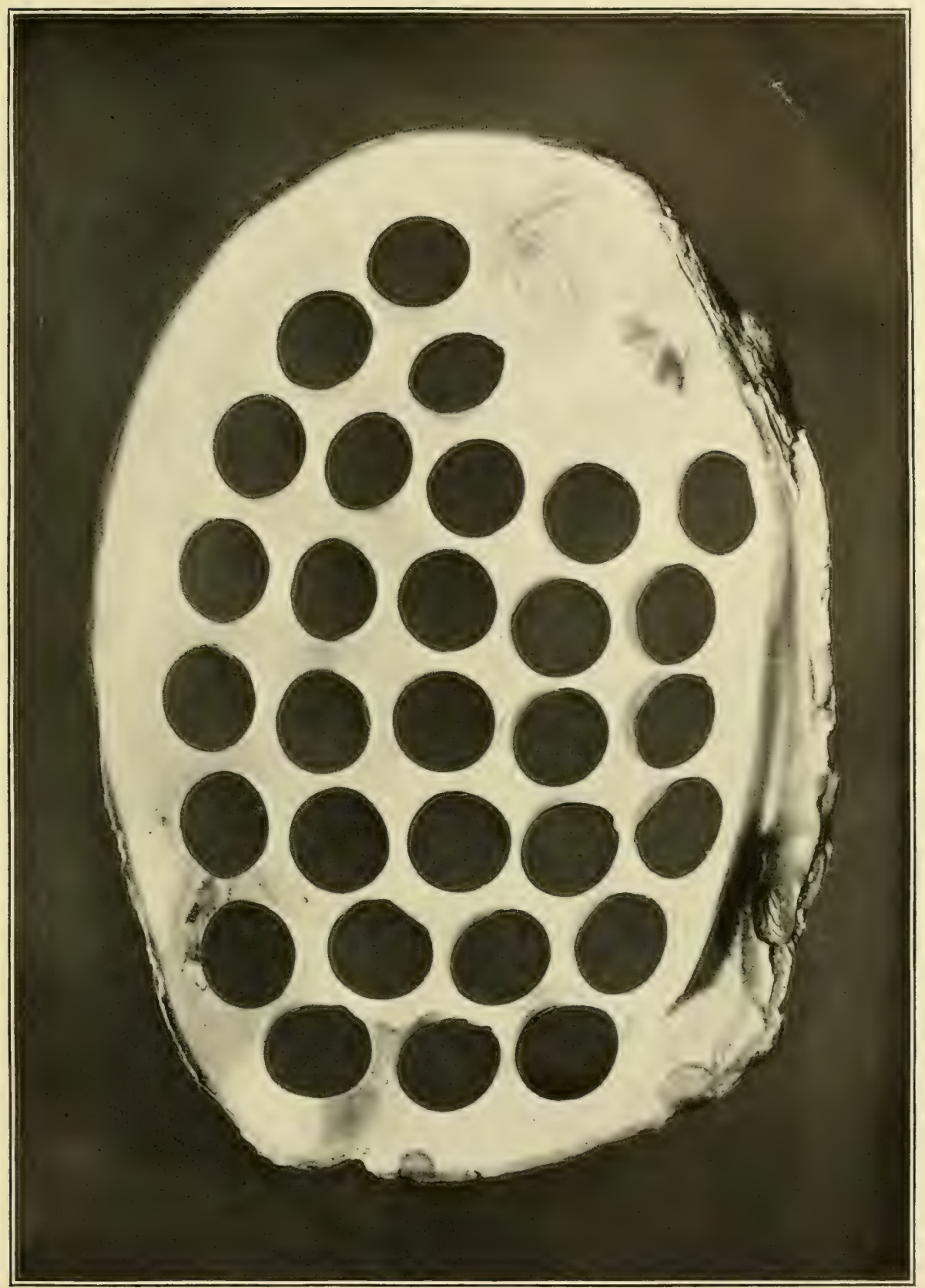

WASHBOARD (QUADRULA HEROS), SIZE $4 \frac{5}{8}$ BY $6 \frac{2}{2}$ INCHES

Five dozen buttons were cut from the entire shell. 



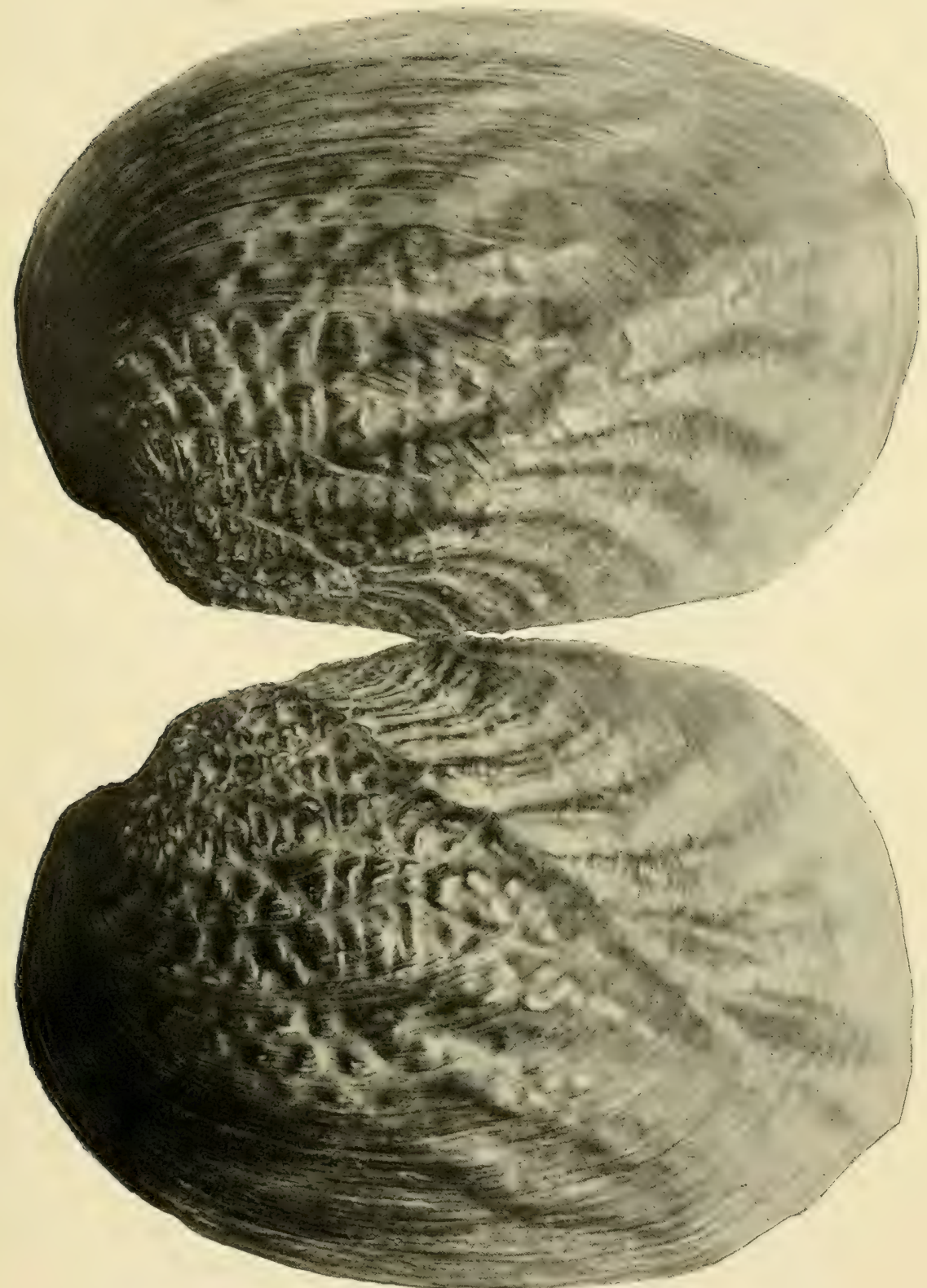

AN EXTERIOR VIEW OF A WASHBOARD (QUADRULA HEROS), SHOWING THE ABNORMAL RIDGE ON THE RIGHT VALVE AND THE VALLEY ON THE LEFT VALVE, WHICH ARE SIGNS OF THE PRESENCE OF A PEARL WITHIN.

In this example the pearl evidently began to form when the shell was about 1 year old. The age of the shell when taken was about 20 years. This shell was found at Bath, III., by Harry Lockwood. 



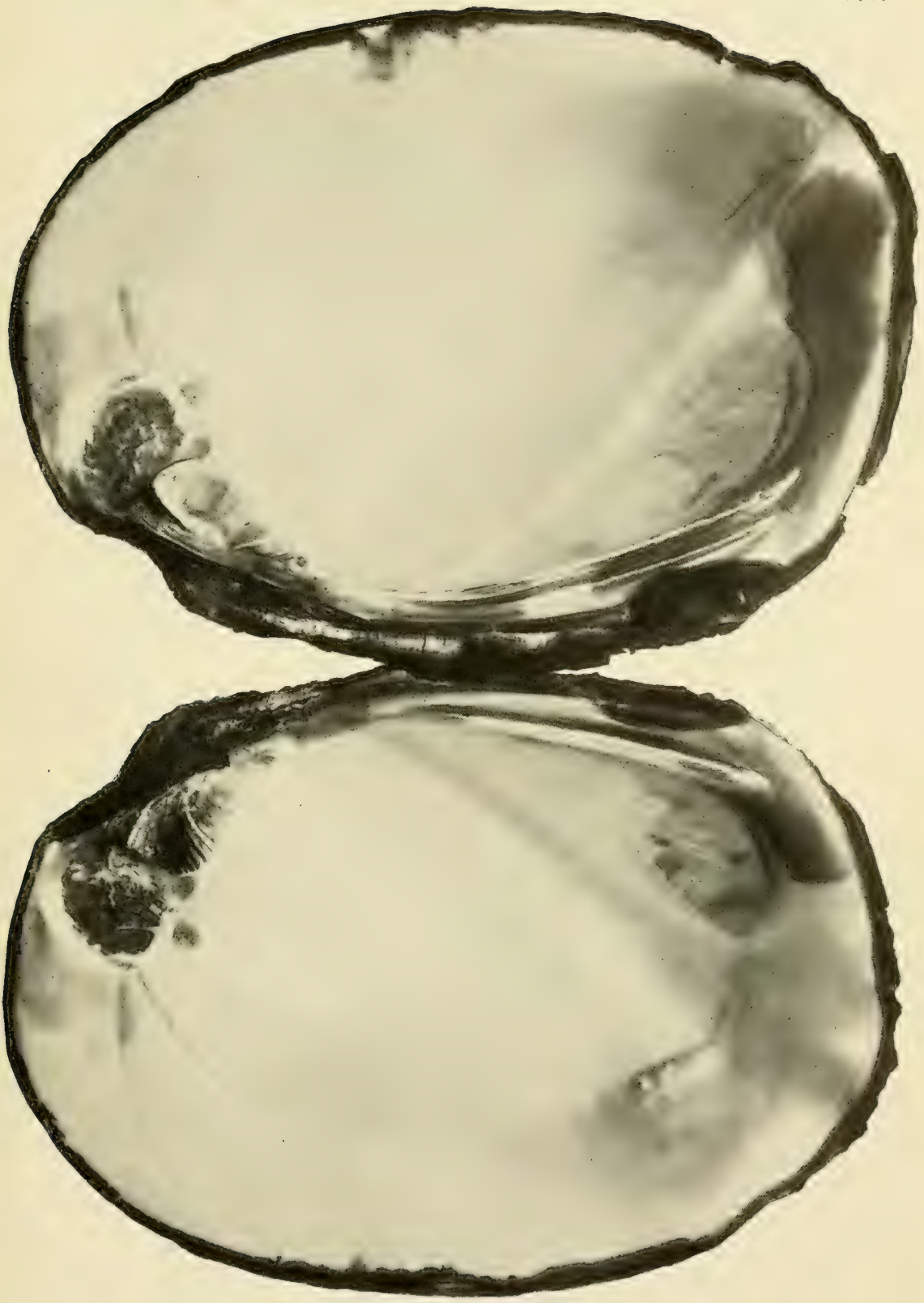

AN INTERIOR VIEW OF THE SHELL REPRESENTED IN PLATE III.

It shows the reverse condition of the ridge and valley, and also the position of the pearl, which weighed 11 grains,

The nacre of the shell, at the point where the pearl was found, is clear. A shell very similar to this gre was

found in the right chute of Grand Island, and contained a 10-grain high-button pearl; but was stained and contained mud. The shell was also stained at the point where the pearl was found. 



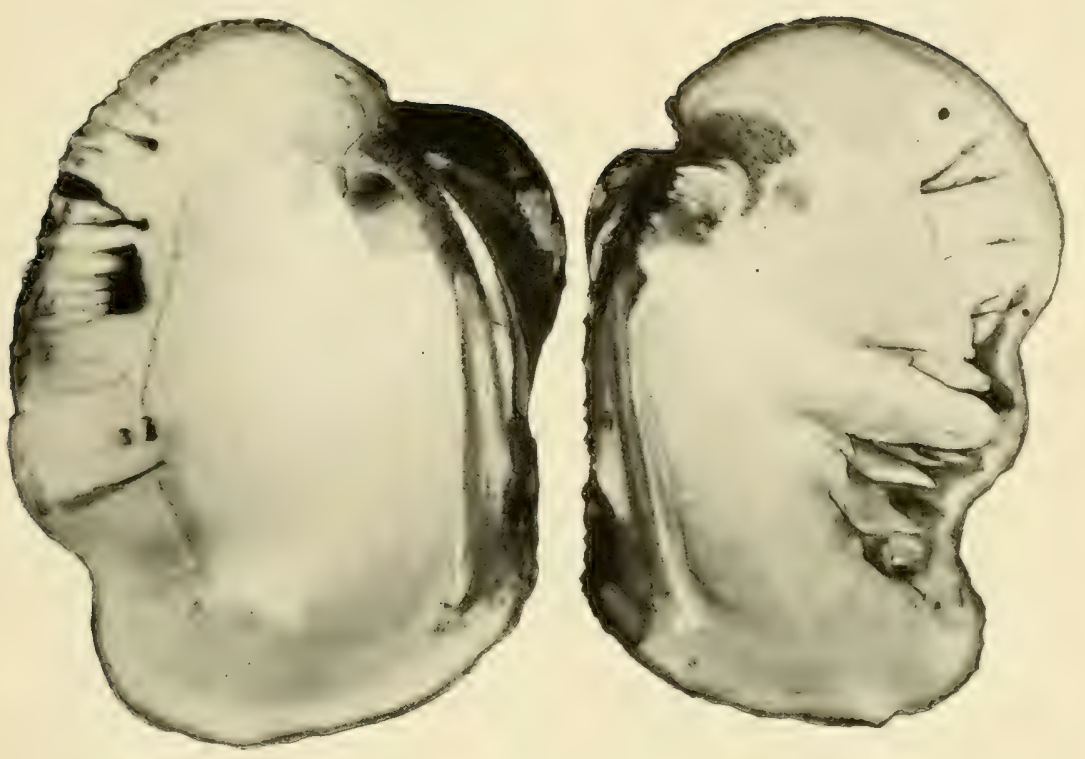

FIG. 1. A THREE-RIDGE (QUADRULA PLICATA) WHICH WAS INJURED AND CONTAINED NO PEARLS.

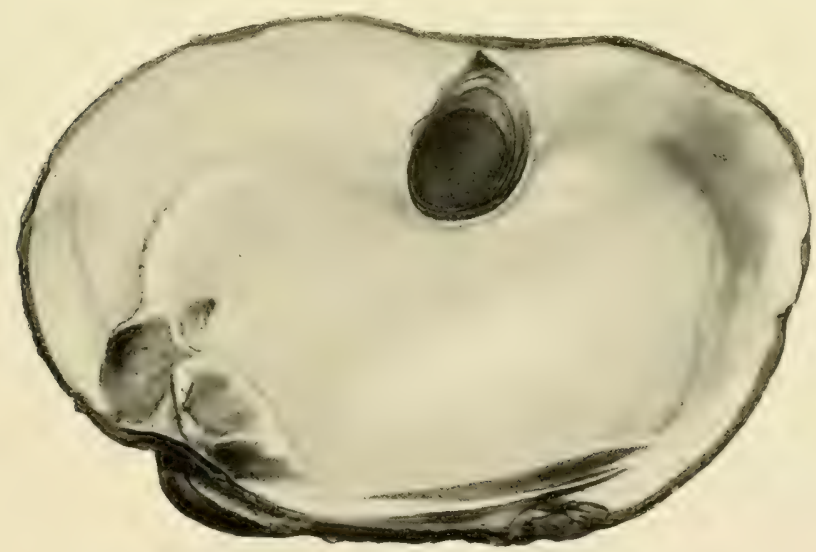

FIG. 2. -ONE VALVE OF A THREE-RIDGE (Q. PLICATA), SHOWING THE CAVITY FROM WHICH AN EMBEDDED 58-GRAIN TURTLEBACK PEARL WAS TAKEN, WHICH WHEN PEELEO PRODUCED A FINE 20-GRAIN HIGH-BUTTON.

This shell, on account of the distortion caused by the pearly growth, is somewhat kidney-shaped. 



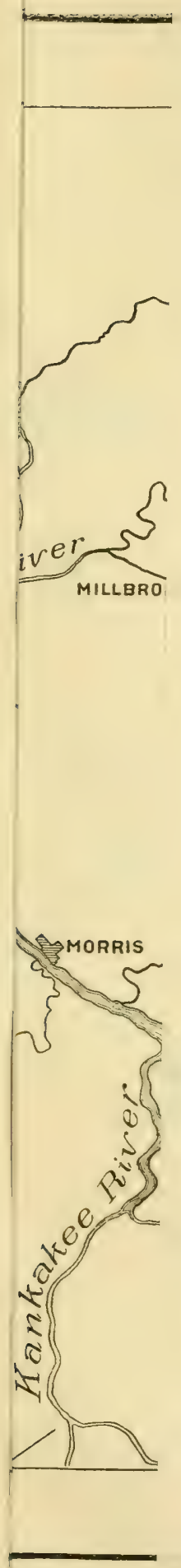


- 


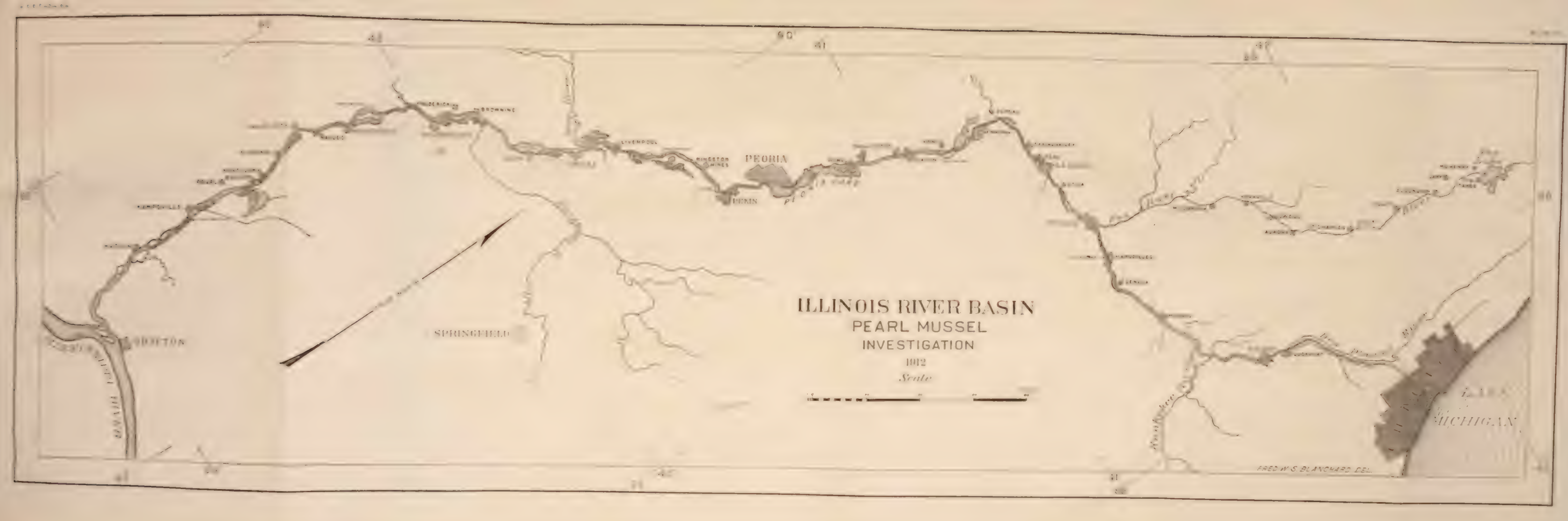





\title{
THE MUSSEL FISHERY OF THE FOX RIVER
}

\author{
By JoHN A. ELDRIDGE
}

\footnotetext{
Appendix VII to the Report of the U. S. Commissioner of Fisheries for 1913
} 


\section{CONTENT.}

General characteristics of Fox River.

Pearls and shelling on Fox River..

Characteristics of the shellers.

Methods in use

Fox River shell

Abundance and value of the shells.

Distribution of mussels in Fox River.

Conclusion 


\section{THE MUUSSEL FISHERY OF THE FOX RIVER.}

By John A. Eldridge.

The portion of the river embraced by the inquiry and dealt with in this report is that between Pistakee Bay, just south of the Wisconsin State line, and the mouth of the river at Ottawa, Ill., a distance of about 90 miles. The conditions of the stream were ascertained in part from observation and experiment, in part from questioning shellers, buyers, and manufacturers. The time of the inquiry proved unfortunate, as cold weather had stopped much of the work carried on during the summer. The brief time devoted to the inquiry prohibited as thorough an examination as was desired.

GENERAL CHARACTERISTICS OF FOX RIVER.

This river, which is about 150 miles in length, rises in Waukesha County, Wis., a little northwest of Milwaukee. It flows south and southwest and enters the Illinois River at Ottawa. (See map, plate VI, preceding paper.)

As described by Forbes and Richardson in their pamphlet on the fishes of Illinois, ${ }^{a}$ the drainage basin of the river is an undulating prairie region with more or less woodland and some swamps. For a distance of nearly 75 miles from its source the fall amounts to only a few inches to the mile. In its passage through Kane and Kendall Counties the fall per mile is about 3 feet, but in La Salle County it increases to about 5 feet per mile, making a descent of nearly 125 feet in the lower 25 miles of its course. Its channel even in its lower 75 miles has a breadth of only one-eighth of a mile.

Above Algonquin the river valley forms one of Chicago's foremost summer resorts; throughout this whole region its banks are lined with summer cottages. Its lower course is through fertile farming country, and several flourishing manufacturing cities lie on its banks. Many power dams have been constructed, which, with their influence on the depth, current, and character of the bottom, strongly affect the Mollusca above them. In most places the water is clear and apparently pure, but of late years the refuse of such places as Aurora

a Forbes, S. A., and Richardson, R. E.: The fishes of Illinois, Natural History Survey of Illinois, vol. III, p. XuTV-V, 1908. 
and Elgin has contaminated it for considerable distances below those cities. This, however, does not seem to have harmed the mussels in these regions.

\section{PEARLS AND SHELLING ON THE FOX.}

Pearls have been hunted on the Fox, as upon other mussel-bearing streams, for many years. During the last six years pearl hunting has increased in extent, but did not assume commercial importance until 1909, when hundreds of shellers were at work, chiefly between Millington and Sheridan. Several good finds were made which attracted others to the river, and by the middle of the summer the whole region from Yorkville to Serena swarmed with pearl hunters.

Certain portions of the river have received much notoriety from the newspapers on account of the pearl finds. These stories are often exaggerated, but, even at the prices named, the value of the finds seldom warrants the space given to them. This attention from the press has given the region near Elgin a reputation for pearl production which it does not deserve. The Fox has produced some extremely good pearls; its yield is much above the average; but most of the better finds have been made in the lower river in the neighborhood of Sheridan. From information gained from shellers and pearlers it is estimated that the average value of a season's pearl find for a constant sheller, between Geneva and Yorkville, would not exceed $\$ 100$. On the mussel bed between Millington and Sheridan, however, extraordinary conditions seem to exist. The average value for finds here has been very high. Many extremely good pearls have been found in the last few years, ranging in price from $\$ 1,000$ to $\$ 1,850$. This region seems to have been one of the most fertile pearl producers in the country, though few valuable pieces were found in 1911. A few shellers still continue to work on this bed in spite of the extreme scarcity of shells, depending for compensation almost entirely upon "finds." Shells found in this district are opened by the knife to avoid injuring the pearls by cooking.

The shells in this locality are almost entirely muckets (Lampsitis ligamentina); the river bed is rock and gravel and the current is strong.

In 1909 shells were sold for the first time. The beds above Yorkville were tapped the following year and shellers were attracted to the work throughout the entire region between Cary and Sheridan. Two years of heavy shelling depleted the beds near the latter place. Further up, especially near Elgin, pearl hunters have increased in numbers, but the scarcity of shells and other conditions closed the season early. Apparently, shelling here as elsewhere along the river has seen its best days. 


\section{CHARACTERISTICS OF THE SHELLERS.}

The shellers and pearlers on the Fox are of a totally different type from those found on some of the larger streams. Although the river has been extensively worked for several years and its pearl finds have received much attention from newspapers, few outside shellers have come in. In some cases shellers from other States have been driven out by threatened prosecution under the State mussel law, which requires a license for nonresidents. As a consequence the nomadic class, found so frequently on some rivers, does not exist on this. Most of the shellers here are persons from the factory or the farm, who take an outing of perhaps several days or a few weeks every summer and try their luck on the river. With few exceptions, they are an intelligent, industrious, pleasant class of people.

The pearlers care little for the value of the shells and usually do not save them; they are left on the bank or thrown into the river to litter up the bed and thus are wasted. In some instances the shells are saved by regular shellers who gather them up along the bank or buy them from the pearlers at 5 to 10 cents a bucket, a rate of from $\$ 3$ to $\$ 7$ a ton.

The regular shellers who work day after day during the summer months depend chiefly on the shells for a living, and consider any pearls found as so much additional profit. Money from pearls may amount to more than from shells, but this can not be depended upon, for often nothing of value is found during the season and the general average for the year is not very high.

The number of regular shellers on the river during September, 1911, was about 70 ; in midseason there were probably as many as 100 . The number of amateur pearlers on the river on some Sundays in the summer ranges perhaps between 400 and 500 .

Many of the regular shellers begin work early in the spring and continue until the season closes October 1. During the season a sheller often gathers as many as 15 or 20 tons of shells, and the daily wages averages $\$ 3$, exclusive of pearl finds.

\section{METHODS IN USE.}

During the greater part of the season the shells are obtained by wading. The outfit consists simply of a pail or burlap bag to hold the mussels and a knife to open them. The regular sheller usually has a boat into which he throws the mussels and opens them by cooking. The mussel bar and mule are but little used, except in cold weather or high water. Some have a wheel at each end serving as a support from the river bottom. The mule which has given most success is a long and narrow one, about 8 feet long by 15 inches wide. In places where there is but little current a windlass is sometimes built upon the 
rear end of the boat carrying 500 feet of rope holding an anchor. The anchor is thrown out at the lower end of a bed, the boat rowed upstream to the extent of the rope, and the bar put into the water. Rewinding the windlass pulls both boat and bar downstream over the bed.

\section{FOX RIVER SHELLS.}

The most characteristic mussel of the Fox is the mucket (Lampsitis Tigamentina), which constitutes 90 per cent of the shells sent to market, and is of high grade, almost equaling the niggerhead as a button shell. Its luster is excellent, and its shape allows perctically the whole shell to be made into buttons with very little wastic. The muckets from the region between Oswego and Yorkville are considered the best; those lower down the river are thinner, and those above are slightly smaller.

On the upper river the mucket is of no importance. The shells saved here run 10 per cent blue-point (Quadrula undulata). They are of poor grade and no market has been found for them. Sixty tons of these shells were lying upon the bank above Cary awaiting a buyer at any price. Where there is little current and a muddy bottom the floater (Anodonta grandis) is chicfly found, while the fat mucket (Lampsitis Tuteola), the mucket (Lampsitis Tigamentina), and the three-ridge (Quadrula plicata) or the blue-point (undulata) are rare. Going downstream, where a strong current and a rocky bottom are found, the mucket appears and increases in numbers until it forms a large percentage of the catch, the floater (Anodonta grandis), the fat mucket (Lampsilis luteola), and the blue-point (Quadrula undulata) decrease, and below Yorkville all are extremely scarce, the latter being seldom seen.

In places where dams check the current and bring about upstream conditions-still water and mud-the three ridges and other shells of the higher river are found in large numbers, while the muckets are scarce.

The fluted shell (Symphynota costata), and the squaw-foot (Strophitus edentulus), are found in larger numbers on the upper stream; the elk-toe (Alasmidonta truncata) more often on the rock bottom lower down; the lady-finger (Unio gibbosus), the Wabash pig-toe (Quadrula rubiginosa), the purple warty-back (Quadrula tuberculata), the pocketbook (Lampsilis ventricosa), and the black sand-shell (Lampsitis recta) are found in rather small numbers along all parts of the river. The warty-back (Quadrula pustulosa) is extremely rare, but two specimens of this species being seen during the investigation out of thousands of shells along the river. It is stated that it was once common. 
While the small number of shells involved in some cases tends to render the figures inexact, the following table showing shells obtained at different points along the stream indicates in general the comparative numbers and distribution of the various species.

\section{ABUNDANCE AND VALUE OF THE SHELLS.}

The price of shells paid by local buyers varies from $\$ 18$ to $\$ 21$ a ton; in some cases prices direct to factory were as high as $\$ 24$.

Estimates for the last three years of the shipment of the Fox River shells are as follows: 1909,10 to 12 carloads; 1910,25 to 30 carloads; 1911, 22 carloads. The catch for next year is expected to be a bare third of that obtained in 1911. More than half of the shells were taken this year from the bed extending from Five Islands to Elgin; several carloads were caught above Elgin, and the rest on the lower river.

Most of the shells are shipped to Iowa factories, and some are sent to Germany every year. There are two blank factories along the river, one at Yorkville with 16 machines, and one at Samonauk with 10 , which form the market for a few carloads each year.

Apparently at one time mussels were scattered quite evenly over the whole Fox River, at any rate as far down as Serena. There is no reason to doubt that shells were as plentiful near Sheridan several years ago as in other parts of the stream. The shelling of recent years, however, has in some places nearly exhausted the mussels, and there is a great difference in those remaining. On the river north of Carpentersville, where little shelling has been done previous to this year, 15 to 20 tons of shells were the usual catch per man in 1911; below Elgin on the Five Islands bed, which has been worked for two years, the catch averaged 10 to 12 tons per man; farther down below Yorkville, 7 tons per man were considered a good yield; on the Millington-Sheridan bed, which is the oldest and hardest worked in the river, but 4 tons a year per man could be caught. It was the general opinion that the shelling for 1911 was 50 per cent less than that of the previous year. The only cause for this is the ravages of man. As far as could be determined, but little loss is caused by animals or by natural conditions. 
Distribution of Mussels in Fox River.

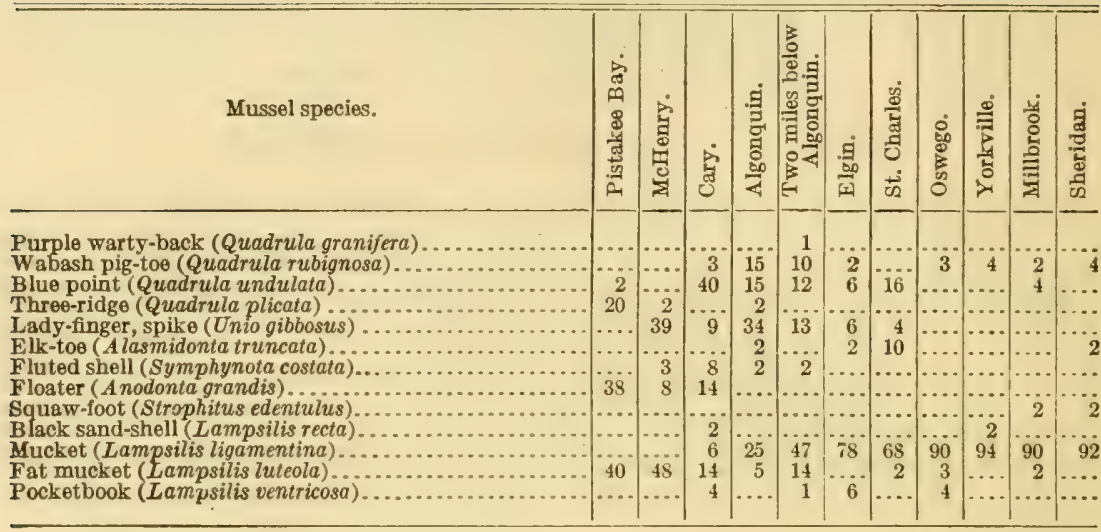

\section{CONCLUSION.}

The foremost fact concerning Fox River shelling is that the mussels are disappearing. The causes that have brought about this condition will probably continue until the beds are completely exhausted, since the unprofessional basis on which the work is conducted will allow its continuance after it has ceased to be profitable. There is but a small professional class which this exhaustion of mussels can influence seriously. This class for the most part will have left the river next year. Yet there are two blank factories near the Fox depending altogether upon it for raw material. Steps should be taken to preserve the mussel beds here for their own sake and because of their importance to the American button manufacturers. The grade of shell is for the most part very good, and the shells have been found in large numbers. The pearls, which have equaled the best in the country, have nearly disappeared.

The conditions observed in 1911 indicated that the industry on this river was doomed to disappear within a year or two unless preventive measures were taken. 



(1)

2.

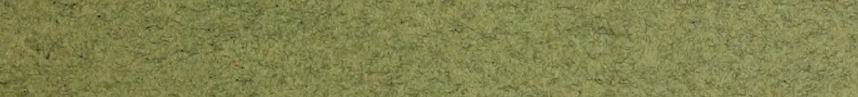

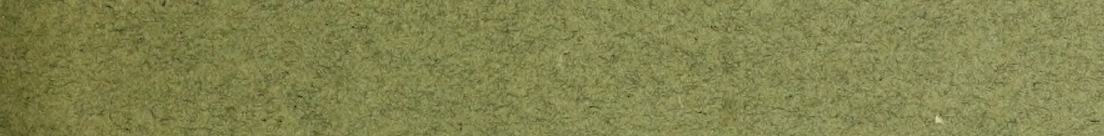

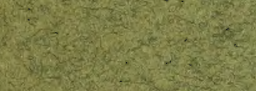

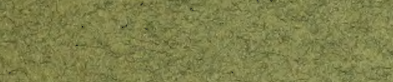

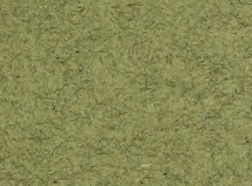

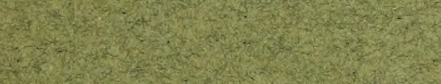

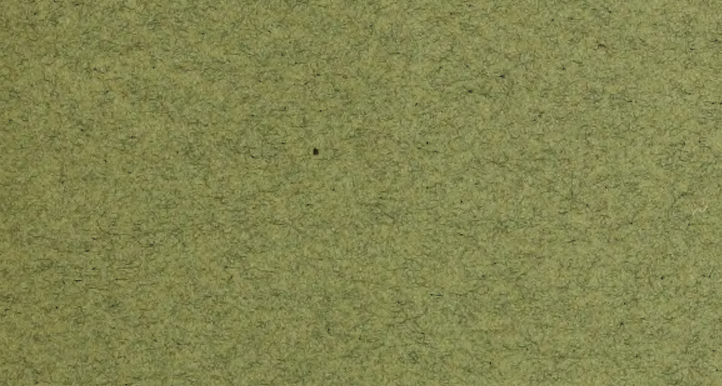

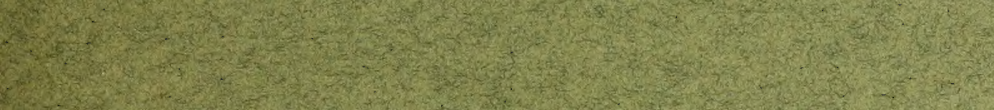

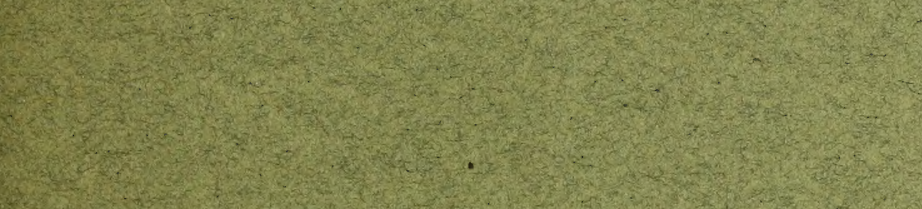

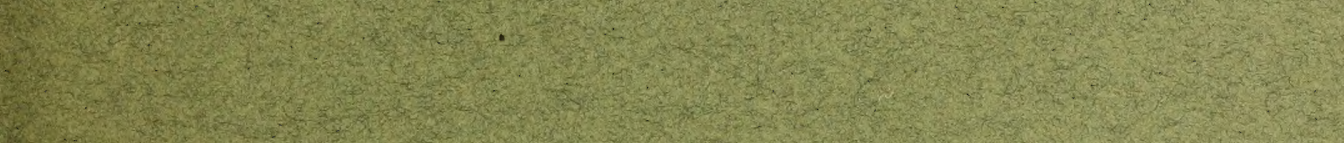

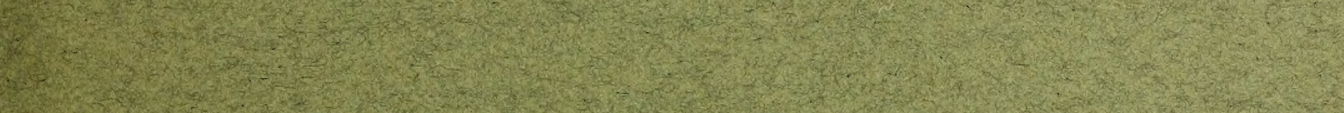
W.

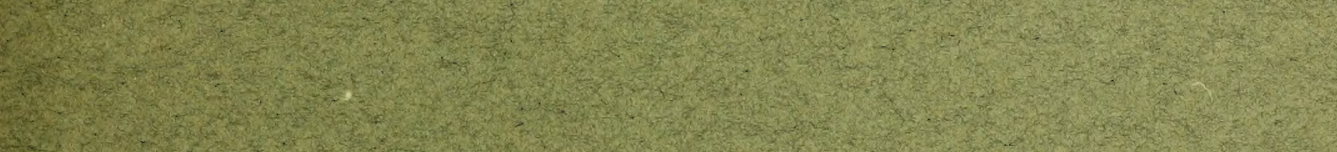
S.t.

a.t.

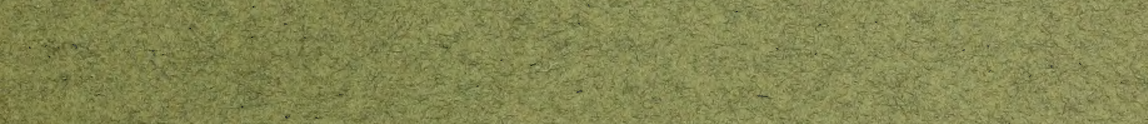

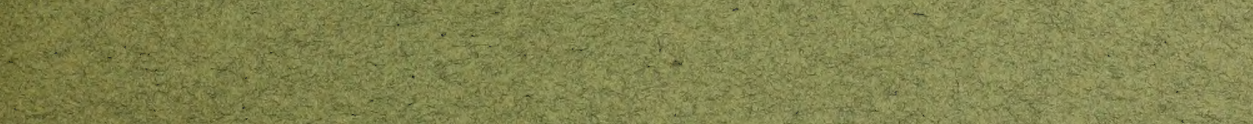

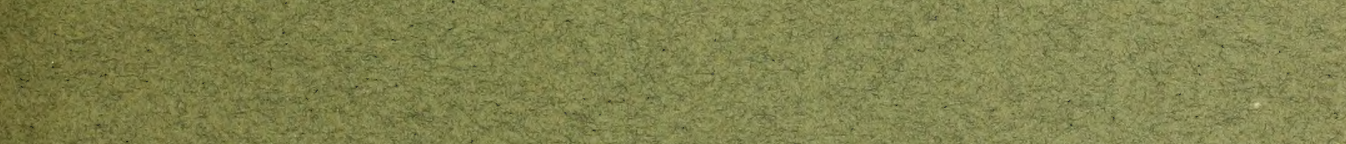
C.

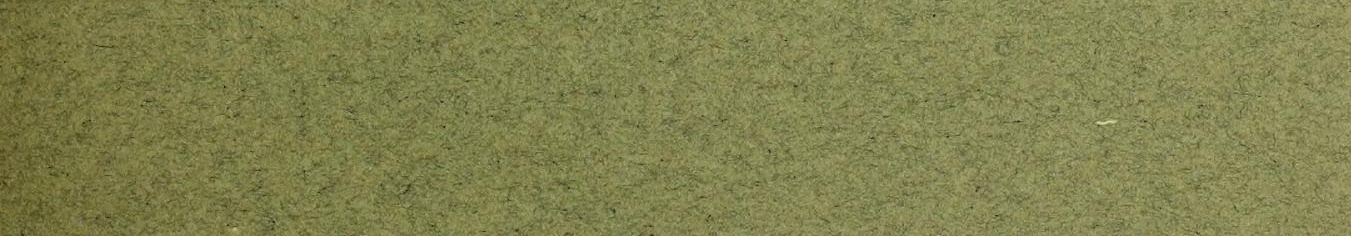
4. H. d.

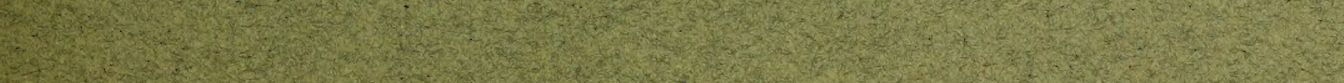


LIBRARY OF CONGRESS

00029036767 